\title{
THE DRUG PROBLEM AND ORGANIZED CRIME, ILLICIT FINANCIAL FLOWS, CORRUPTION AND TERRORISM
}

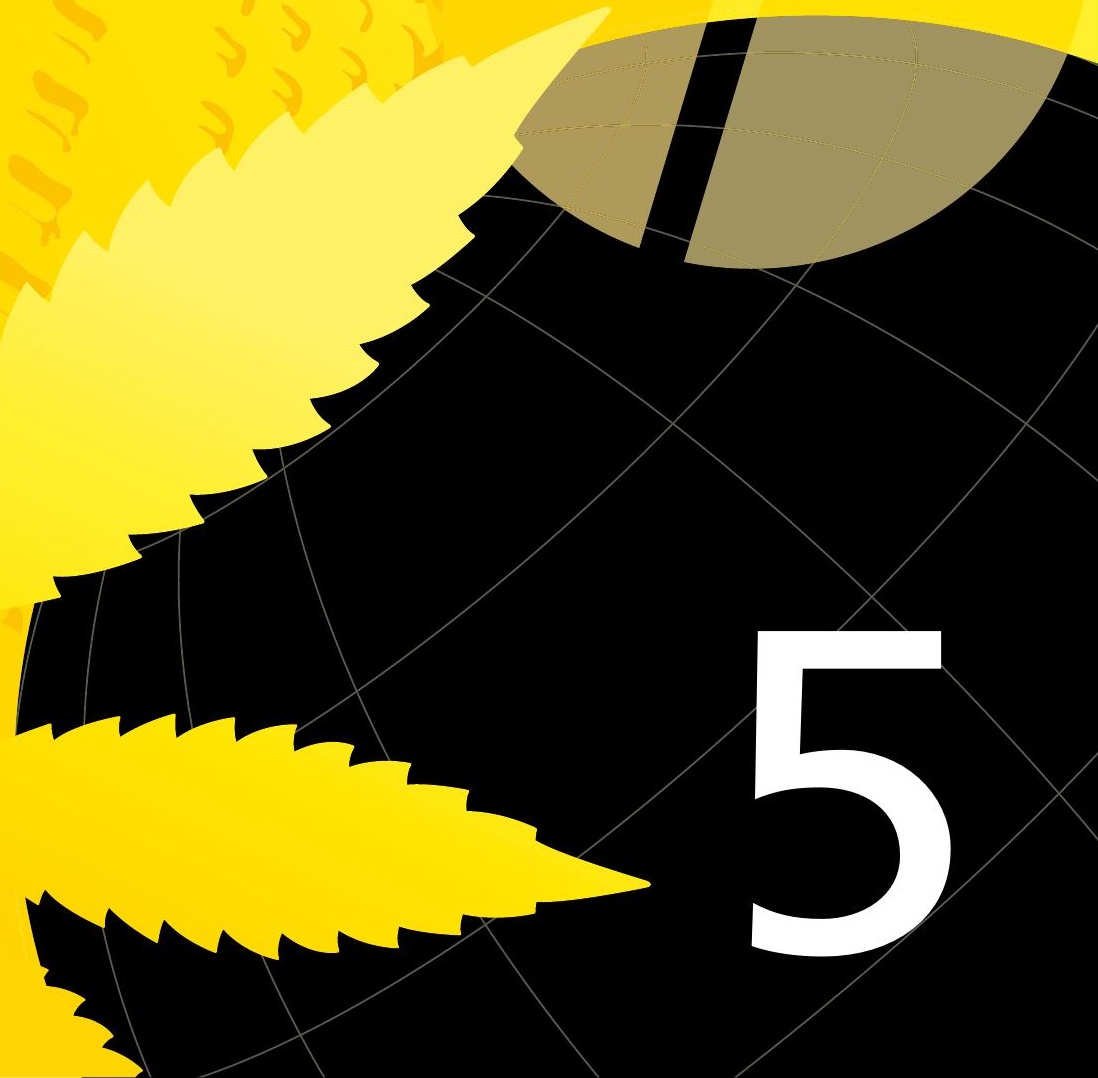


This booklet constitutes the fifth part of the World Drug Report 2017.

(C) United Nations, May 2017. All rights reserved worldwide.

ISBN: 978-92-1-148297-3

eISBN: 978-92-1-060628-8

United Nations publication, Sales No. E.17.XI.11

This publication may be reproduced in whole or in part and in any form for educational or non-profit purposes without special permission from the copyright holder, provided acknowledgement of the source is made. The United Nations Office on Drugs and Crime (UNODC) would appreciate receiving a copy of any publication that uses this publication as a source.

Suggested citation:

United Nations Office on Drugs and Crime, World Drug Report 2017

(ISBN: 978-92-1-148291-1, eISBN: 978-92-1-060623-3, United Nations publication, Sales No. E.17.XI.6).

No use of this publication may be made for resale or any other commercial purpose whatsoever without prior permission in writing from UNODC. Applications for such permission, with a statement of purpose and intent of the reproduction, should be addressed to the Research and Trend Analysis Branch of UNODC.

\section{DISCLAIMER}

This booklet has not been formally edited. The content of this publication does not necessarily reflect the views or policies of UNODC or contributory organizations, nor does it imply any endorsement.

Comments on the report are welcome and can be sent to:

Division for Policy Analysis and Public Affairs

United Nations Office on Drugs and Crime

PO Box 500

1400 Vienna

Austria

Tel: (+43) 1260600

Fax: (+43) 1260605827

E-mail:wdr@unodc.org

Website: www.unodc.org/wdr2017 


\section{PREFACE}

I am proud to say that this year we are marking 20 years of the World Drug Report.

Over the past two decades, the United Nations Office on Drugs and Crime (UNODC) has been at the forefront of global research into complex areas of drug use and supply, supporting international cooperation and informing policy choices with the latest estimates, information on trends and analysis.

This year we are launching a new format, with the report available as five separate booklets: the executive summary, together with the report's conclusions and policy implications; a global overview of drug use and supply; a market analysis of plant-based drugs; a market analysis of synthetic drugs; and a thematic booklet on the links between drugs and organized crime, illicit financial flows, corruption and terrorism. We have done this in response to readers' needs and to improve user-friendliness, while maintaining the rigorous standards expected from the Office's flagship publication.

The 2017 report comes at a time when the international community has acted decisively to achieve consensus on a way forward for joint action.

The outcome document unanimously adopted at last year's special session of the General Assembly on the world drug problem contains more than 100 concrete recommendations for implementing balanced, comprehensive and integrated approaches to effectively addressing and countering the world drug problem.

Moreover, at its sixtieth session, in March 2017, the Commission on Narcotic Drugs adopted resolution $60 / 1$, reinforcing commitment to implementing the outcome document and charting a course to the 2019 target date of the 2009 Political Declaration and Plan of Action on the world drug problem, as well as strengthening action towards the Plan of Action's agreed goals and targets.
As the World Drug Report 2017 clearly shows, there is much work to be done to confront the many harms inflicted by drugs, to health, development, peace and security, in all regions of the world.

Globally, there are an estimated minimum of 190,000 — in most cases avoidable — premature deaths from drugs, the majority attributable to the use of opioids.

The terrible impact of drug use on health can also be seen in related cases of HIV, hepatitis and tuberculosis.

Much more needs to be done to ensure affordable access to effective scientific evidence-based prevention, treatment and care for the people who desperately need them, including those in prison settings. As just one example, this year's report highlights the need to accelerate accessibility to the treatment of hepatitis $\mathrm{C}$, a disease whose negative health impact on people who use drugs is far greater than that of HIV/AIDS.

Recent attention has focused on the threats posed by methamphetamine and new psychoactive substances (NPS). However, as the report shows, the manufacture of both cocaine and opioids is increasing. These drugs remain serious concerns, and the opioid crisis shows little sign of stopping.

The World Drug Report 2017 further looks at the links with other forms of organized crime, illicit financial flows, corruption and terrorism. It draws on the best available evidence and, most of all, highlights the fact that much more research needs to be carried out in these areas.

Corruption is the great enabler of organized crime, and opportunities for corruption exist at every stage of the drug supply chain. However, too little is known about how different types of corruption interact with drug markets.

The outcome document of the special session of the General Assembly on the world drug problem and 
Security Council resolutions express concern about terrorist groups profiting from drug trafficking, among other forms of transnational organized crime.

It is well established that there are terrorists and non-State armed groups profiting from the drug trade - by some estimates, up to 85 per cent of opium poppy cultivation in Afghanistan is in territory under influence of the Taliban.

However, evidence on the organized crime-terrorism nexus remains patchy at best. Moreover, these links are not static. Relations between organized crime and terrorists groups are always evolving, much like drug markets themselves.

As we have seen with the NPS market, drug use, supply, trafficking routes and the substances themselves continue to shift and diversify at alarming speed.

Drugs continue to represent a major source of revenue for organized crime networks, but business models are changing, with criminals exploiting new technologies, such as the darknet, that are altering the nature of the illicit drug trade and the types of players involved, with looser, horizontal networks and smaller groups becoming more significant. New ways of delivering drugs further point to the need to involve other sectors such as postal services in the fight against drug trafficking.

Clearly, countries must be able to act and react to an ever-changing and formidable array of threats and problems. UNODC is fully engaged in strengthening responses, working closely with our United Nations partners and in line with the international drug control conventions, human rights instruments and the 2030 Agenda for Sustainable Development, which are themselves complementary and mutually reinforcing.
As the special session of the General Assembly and the recent session of the Commission on Narcotic Drugs have shown, the international community is equipped to respond swiftly and decisively to global drug-related challenges.

For example, in March, the Commission scheduled two precursors and an analogue to the scheduled drug fentanyl. This important step will make it harder for criminals to illicitly manufacture fentanyl and its analogues and, I hope, can help to stem the tragic increase in opioid overdoses in recent years.

However, there remains an enormous need for capacity-building and technical assistance, and funding continues to fall far short of political commitment. Further resources are urgently needed to help all Member States implement the recommendations contained in the outcome document of the special session of the General Assembly and achieve related targets under the Sustainable Development Goals.

The many evolving drug challenges also highlight the importance of prevention - science- and rightsbased drug use prevention - but also prevention of crime, corruption, terrorism and violent extremism, in line with commitments under the conventions and United Nations standards and norms.

Finally, I ask all Governments to help us improve the evidence base for these reports. Areas such as the links between drugs, terrorism and insurgency clearly touch upon sensitive intelligence, and there are legitimate concerns about compromising sources, collection and operations. But if we want to effectively address drug challenges we need to strengthen international cooperation and information-sharing to the extent possible, to close the gaps and ensure that joint action is targeted, effective and timely.

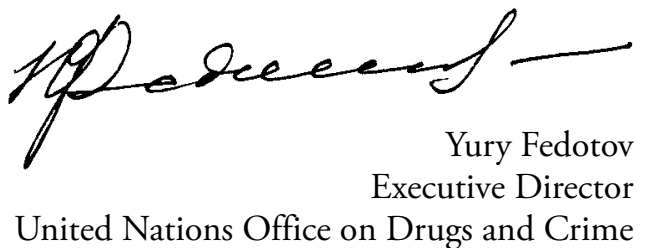




\section{CONTENTS}

\section{BOOKLET 1 EXECUTIVE SUMMARY - CONCLUSIONS AND POLICY IMPLICATIONS}

\section{BOOKIFT 2 GLOBAL OVERVIEW OF DRUG DEMAND AND SUPPLY}

BOOKLE 12 Latest trends, cross-cutting issues

\section{BOOKLET 3 MARKET ANALYSIS OF PLANT-BASED DRUGS \\ Opiates, cocaine, cannabis}

\section{BOOKLET 4}

\section{MARKET ANALYSIS OF SYNTHETIC DRUGS}

Amphetamine-type stimulants, new psychoactive substances

\section{$\begin{array}{ll}\text { BOOKLET } 5 & \text { THE DRUG PROBLEM AND ORGANIZED CRIME, } \\ \text { ILLICIT FINANCIAL FLOWI, CORRUPTION AND TERRORISM }\end{array}$}

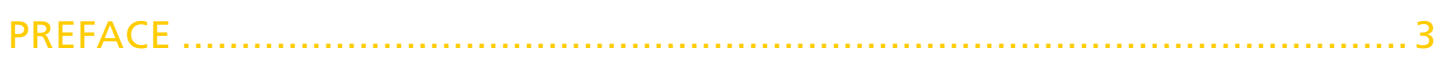

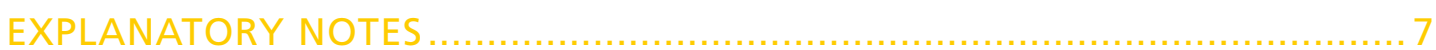

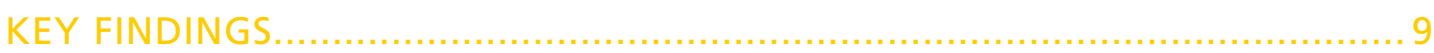

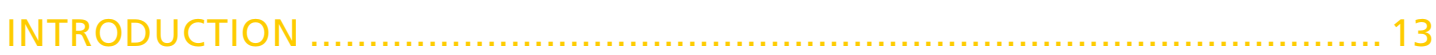

A. THE DRUG PROBLEM AND ORGANIZED CRIME .................................. 15

Major transformation of organized crime in recent decades...........................................................15

Evolution of links between organized crime and drug trafficking ..............................................18

Drugs remain an important market for organized crime............................................................ 18

State responses to drug trafficking groups...................................................................................19

B. DRUG PROCEEDS AND ILLICIT FINANCIAL FLOWS .............................. 21

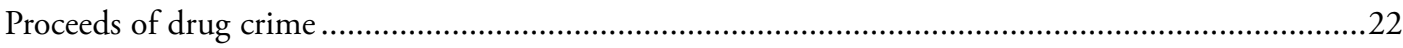

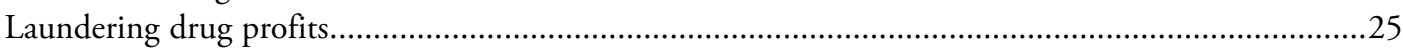

Cross-border laundering: illicit financial flows .........................................................................27

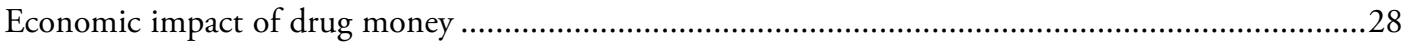

C. THE DRUG PROBLEM AND CORRUPTION ....................................... 30

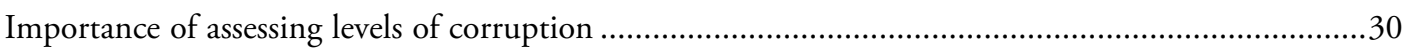

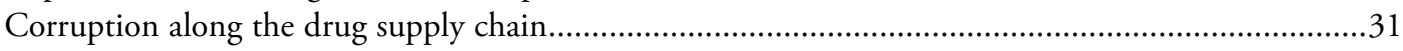

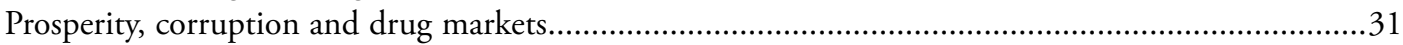

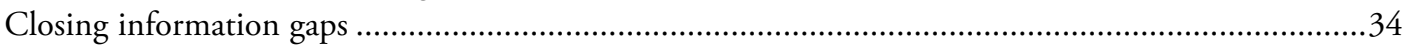

D. DRUGS, TERRORISM AND INSURGENCY ........................................ 34

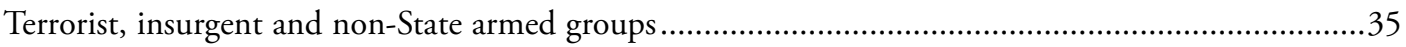

Funding of terrorist, insurgent and non-State armed groups .....................................................37

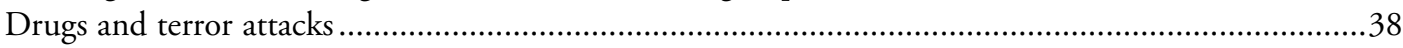

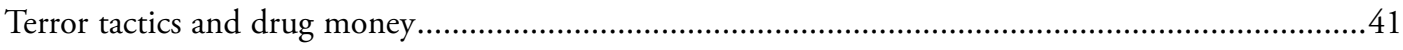

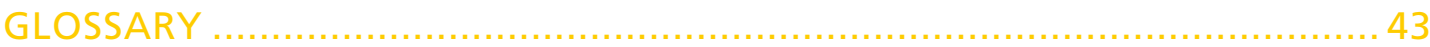

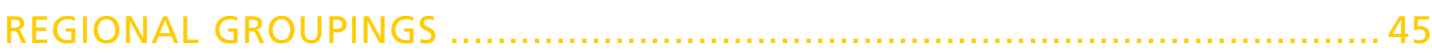




\section{Acknowledgements}

The World Drug Report 2017 was prepared by the Research and Trend Analysis Branch, Division for Policy Analysis and Public Affairs, United Nations Office on Drugs and Crime, under the supervision of Jean-Luc Lemahieu, Director of the Division, and Angela Me, Chief of the Research and Trend Analysis Branch.

General coordination and content overview Chloé Carpentier

Angela Me

Analysis and drafting

Thomas Pietschmann

Data management and estimates production

Coen Bussink

Lorenzo Vita

Editing

Joseph Boyle

Jonathan Gibbons
Graphic design and production

Anja Korenblik

Suzanne Kunnen

Kristina Kuttnig

Coordination

Francesca Massanello

Administrative support

Anja Held

Iulia Lazar

\section{Review and comments}

The World Drug Report 2017 benefited from the expertise and invaluable contributions of UNODC colleagues in the Drug Prevention and Health Branch of the Division for Operations; the Corruption and Economic Crime Branch, the Organized Crime and Illicit Trafficking Branch and the Terrorism Prevention Branch of the Division for Treaty Affairs; and the Research and Trend Analysis Branch of the Division for Policy Analysis and Public Affairs.

The Research and Trend Analysis Branch acknowledges the contribution to the section on drugs, terrorism and insurgency in the present booklet by the Illicit Crop Monitoring team of the UNODC country office in Afghanistan.

The Research and Trend Analysis Branch also acknowledges the invaluable contributions and advice provided by the World Drug Report Scientific Advisory Committee:

Jonathan Caulkins

Paul Griffiths

Marya Hynes

Vicknasingam B. Kasinather

Letizia Paoli

Charles Parry

Peter Reuter

Francisco Thoumi

Alison Ritter

Brice De Ruyver

UNODC gratefully acknowledges the comments and advice provided on the section on drugs, terrorism and insurgency by the Analytical Support and Sanctions Monitoring Team of the United Nations Security Council. 


\section{EXPLANATORY NOTES}

The boundaries and names shown and the designations used on maps do not imply official endorsement or acceptance by the United Nations. A dotted line represents approximately the line of control in Jammu and Kashmir agreed upon by India and Pakistan. The final status of Jammu and Kashmir has not yet been agreed upon by the parties. Disputed boundaries (China/India) are represented by crosshatch owing to the difficulty of showing sufficient detail.

The designations employed and the presentation of the material in the World Drug Report do not imply the expression of any opinion whatsoever on the part of the Secretariat of the United Nations concerning the legal status of any country, territory, city or area, or of its authorities or concerning the delimitation of its frontiers or boundaries.

Countries and areas are referred to by the names that were in official use at the time the relevant data were collected.

All references to Kosovo in the World Drug Report, if any, should be understood to be in compliance with Security Council resolution 1244 (1999).

Since there is some scientific and legal ambiguity about the distinctions between "drug use", "drug misuse" and "drug abuse", the neutral terms "drug use" and "drug consumption" are used in the World Drug Report.
All uses of the word "drug" in the World Drug Report refer to substances under the control of the international drug control conventions.

All analysis contained in the World Drug Report is based on the official data submitted by Member States to the United Nations Office on Drugs and Crime through the annual report questionnaire unless indicated otherwise.

The data on population used in the World Drug Report are taken from: United Nations, Department of Economic and Social Affairs, Population Division, World Population Prospects: The 2015 Revision.

References to dollars (\$) are to United States dollars, unless otherwise stated.

References to tons are to metric tons, unless otherwise stated. R stands for the correlation coefficient, used as measure of the strength of a statistical relationship between two or more variables, ranging from 0 to 1 in case of a positive correlation or from 0 to -1 in case of a negative correlation. 



\section{KEY FINDINGS}

\section{Organized crime groups branch out}

Organized crime groups have widened their portfolio of illicit activities. New crime areas such as cybercrime and environmental crime have emerged. Fewer groups are exclusively dedicated to drug trafficking, while more are also operating in other illicit sectors.

Almost two thirds of drug trafficking groups operating in countries in the European Union are involved in more than one crime area, according to research by the European Police Office (Europol), and that figure has been rising for years. Drug trafficking groups in Europe are frequently also involved in the counterfeiting of goods, trafficking in human beings, smuggling of migrants and trafficking in weapons.

\section{Continued importance of drugs to organized crime groups}

In 2014, transnational organized crime groups across the globe were estimated to have generated between approximately one fifth and one third of their revenues from drug sales.

Europol identified some 5,000 international organized crime groups operating in countries of the European Union in 2017, and estimated that more than one third were involved in drug trafficking. This makes drug trafficking more widespread across organized crime than organized property crime, smuggling of migrants, trafficking in human beings, excise fraud or any other illicit activity.

\section{Drug trafficking no longer the preserve of large criminal groups}

Groups with a strong hierarchical structure, such as those in Mexico and Japan, and to some extent in the Russian Federation, continue to be involved in the drug trade. Hierarchical, top-down organizations are still the most widespread type of organized crime group in Europe, according to Europol.

However, there is evidence that looser, horizontal networks are becoming increasingly significant. In 2017, Europol estimated that such networks accounted for 30-40 per cent of organized crime groups operating in countries in the European Union.

\section{Technology's role in creating relatively low-risk drug markets}

The mobile communications revolution has offered new opportunities to traffickers. They no longer need personal contact with clients; instead, low-level "runners" can collect cash and dealers can let the customer know where to collect their drugs using messages sent over encrypted networks.

The darknet allows users to buy drugs with a cryptocurrency, such as bitcoin, and have their purchases delivered to them in a concealed manner. Typical buyers are recreational users of cannabis, "ecstasy", cocaine, hallucinogens and NPS. They are less likely to order heroin or methamphetamine. Although the darknet accounts for only a small percentage of drug sales, the market has been growing rapidly in recent years.

\section{About 30 per cent of cocaine proceeds contributes to illicit financial flows}

About 30 per cent of the proceeds of cocaine sales at the global level was laundered abroad in 2009, according to a model developed by UNODC. A 2016 study based on interviews with drug crime convicts in Italy came to a similar conclusion, suggesting that roughly one third of the money spent by cocaine users was being laundered across borders.

\section{Drug money can make countries poorer}

In the short term, an inflow of drug money can boost investment and local gross domestic product. But the long-term effects tend to be negative, particularly when drug-related proceeds comprise a sizeable portion of the total economy of a community or a country. In this scenario, drug money has 
the potential to inflate property prices, distort export figures, create unfair competition, reinforce skewed income and wealth distributions and increase corruption. In the process, legitimate businesses, without access to illicit funds, may be squeezed out of the market and new legitimate investments may not take place.

The rise of an illicit economy helps to weaken the rule of law and facilitates corruption, which in turn reinforces the illicit drug sector.

Studies suggest that an injection of laundered money, including from illicit drug activities, is associated with reductions in overall annual economic growth rates, particularly in smaller and less developed countries. One estimate, based on a study of 17 countries of the Organization for Economic Cooperation and Development, suggests that a $\$ 1$ billion increase in money-laundering could reduce overall economic growth by between 0.03 and 0.06 percentage points.

\section{Corruption exists all along the drug supply chain}

At each stage of the drug supply chain, there are opportunities for corruption. At the production level, farmers may bribe eradication teams, producers may bribe judges and police officers, and manufacturers may exploit workers in chemical companies in order to get hold of precursor chemicals. Further down the chain, traffickers bribe customs officials and take advantage of weaknesses in transport firms. At the consumer level, users can get drugs through corrupt doctors and pharmacists.

\section{Corruption, the illicit drug trade and poverty reinforce each other}

Corruption entrenches poverty by discouraging foreign investment, according to World Bank research. In a narco-economy, this is doubly true. Foreign firms, seeing the corrupted justice system and pervasive money-laundering that characterize narco-economies, are unlikely to make or increase investments.

Corruption also increases the level of income inequality, according to International Monetary Fund research. Higher levels of income inequality are known to encourage drug trafficking and corruption. In fact, the drug industry may perpetuate and exacerbate income inequality, which may in turn cause the expansion of drug production and trafficking.

Lack of understanding of the relationship between drugs and corruption

Many studies have focused on specific events or geographical areas; others have relied on perceptions of corruption. While these approaches have certain strengths, they highlight a paucity of data on the links between drugs and corruption across countries. For example, while, intuitively, such a correlation is anticipated, in terms of research, little is known about the way that different types of corruption interact with drug markets and political structures; the way that corruption and violence coexist also needs further investigation.

\section{United Nations-designated terrorist groups: Taliban continues to benefit}

The Taliban's involvement in the drug trade is well documented. It has taxed entities involved in illicit opiate production, manufacture and trafficking in Afghanistan. Further, the Consolidated United Nations Security Council Sanctions List contains a number of Taliban leaders who are accused of direct involvement in drug trafficking.

UNODC estimated that non-State armed groups raised about $\$ 150$ million in 2016 from the Afghan illicit opiate trade in the form of taxes on the cultivation of opium poppy and trafficking in opiates. The overall drug-related income, however, may be higher still. The Security Council Committee established pursuant to resolution 1988 (2011) estimated the overall annual income of the Taliban at about $\$ 400$ million, half of which is likely to be derived from the illicit narcotics economy.

\section{Role of the Revolutionary Armed Forces of} Colombia in the drug trade

The involvement of the Revolutionary Armed Forces of Colombia (FARC) in the drug trade in Colombia goes back decades. At various times, they have provided security for coca crops, taxed the introduction of precursor chemicals and the use of landing strips, sold coca paste and become involved in the intraregional cocaine trade. 
FARC agreed in 2016 to halt its involvement in the drug business after the peace agreement signed with the Government.

\section{Evidence implicating other groups is thin}

Media reports and some evidence from official sources link a number of other terrorist, insurgent and non-State armed groups to the drug trade. For example, media reports claim that Islamic State in Iraq and the Levant (ISIL) and other armed groups in Iraq and the Syrian Arab Republic produce and consume "captagon" tablets — typically amphetamine mixed with caffeine. The group operates in an area likely to be a manufacturing hub, according to seizure data, but no conclusive evidence has emerged so far, as other groups also operate in the same area.

Boko Haram has also reportedly helped drug traffickers to smuggle heroin and cocaine across West Africa. During the trial of Boko Haram members in Chad, the court of appeal heard that considerable quantities of psychotropic substances had been recovered and that Boko Haram members were regularly involved in the trafficking in and consumption of those substances. Further north, some evidence suggests that Al-Qaida in the Islamic Maghreb has been involved in cannabis and cocaine trafficking, or at least in protecting traffickers, but that its overall income from the drug sector appears to have been rather modest.

\section{Income from drugs key for some terrorist,} insurgent and non-State armed groups

Much depends on the location of a particular group. Some have benefited from being based in areas where drug crops flourish. Groups that aspire to control large amounts of territory need huge financial resources, and have relied on organized crime and the illicit drug trade to fund their ambitions.

Just one revenue stream of many for most groups

Terrorist and other non-State armed groups are adept at tapping into multiple sources of revenue. If drug profits dry up, the groups may move into extortion, kidnapping for ransom, bank robberies, sale of natural resources or sale of cultural artefacts. However, groups aiming simply to stage shocking attacks on civilians can do so with negligible financial investment.
Huge variation in estimates of finances of terrorist, insurgent and other non-State armed groups

Little reliable data exist for estimating the overall wealth of terrorist, insurgent and other non-State armed groups, making it tricky to estimate the importance of the drug trade. Forbes International attempted to compile a list, but the income of the wealthiest 10 groups (around $\$ 5$ billion together) was highly skewed, ranging from $\$ 25$ million to $\$ 2$ billion per group.

\section{Limited evidence on drugs, terrorism and insurgency}

Much of the work in this area tracks a small number of groups, or builds on sources with an interest in emphasizing or diminishing certain links. Most information on terrorism is collected by intelligence agencies and is classified, meaning that researchers have to rely on media reports and studies issued by non-governmental organizations and think tanks. 



\section{INTRODUCTION}

Although presented as a stand-alone publication, this booklet constitutes the fifth part of the World Drug Report 2017. It investigates the connection between the drug problem and four areas of international concern - organized crime, illicit financial flows, corruption and terrorism/insurgency. The discussion draws on research by UNODC and a wide range of outside sources to provide an up-todate assessment of these complex relationships.

The booklet highlights where our knowledge is lacking and provides ideas for areas of further research. It begins by sketching out the transformation in drug-related organized crime from the dismantling of the Colombian cartels in the 1990s, to the use of drones, the darknet and the emergence of network organizations in recent years. Next, the consequences of drug money in the international system are analysed. The booklet then discusses the ways in which the drug trade and corruption reinforce each other. Finally, the extent to which groups including the Taliban, Islamic State in Iraq and the Levant (ISIL) and the Revolutionary Armed Forces of Colombia (FARC) have benefited from drug money is discussed in depth, along with a broader analysis of the links between terrorist, insurgent and other nonState armed groups, violence and the illicit drug trade.

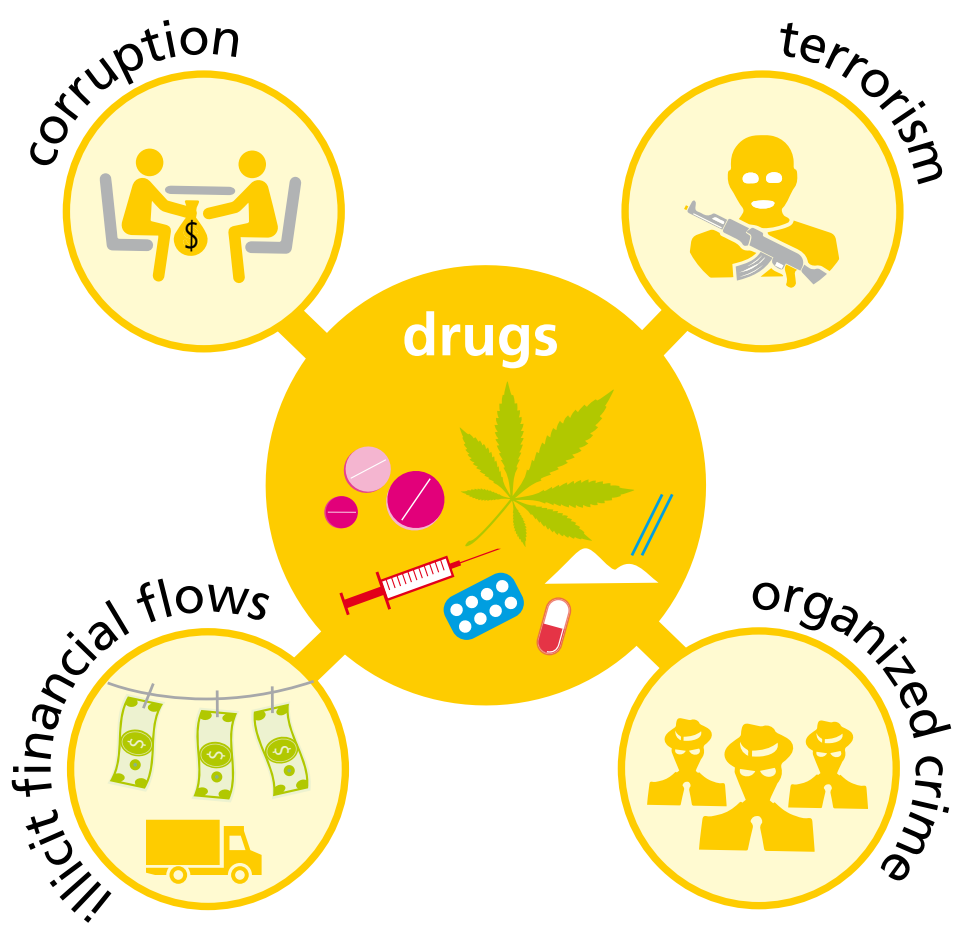





\section{A. THE DRUG PROBLEM AND ORGANIZED CRIME}

Organized crime groups have existed in various parts of the world for centuries, 1, 2, 3 and they have been involved in the international drug trade for almost 100 years. ${ }^{4,5}$ Over this time, their operations and structures have been transformed by technology, legislation and shifts in politics; many of the most infamous drug trafficking gangs have come and gone.

The importance of drug trafficking for organized crime seems to have reached a peak in the late 1980s and early 1990s, after which new "business opportunities" emerged. Many of the current activities of organized crime groups hardly existed a few decades ago. Nevertheless, drug trafficking can serve as an incubator for the development of organized crime groups. At other times, it may also be an activity that organized crime groups take up after their establishment in other illicit markets.

Overall, drugs continue to play an important role for organized crime groups, which have found new ways to smuggle and sell their produce, hide their profits and intimidate their rivals, influence politicians and eliminate their enemies.

\section{What is an organized crime group?}

"A structured group of three or more persons, existing for a period of time and acting in concert with the aim of committing one or more serious crimes or offences ... in order to obtain, directly or indirectly, a financial or other material benefit.

United Nations Convention against Transnational

Organized Crime, 2000

Cyrille Fijnaut, "Searching for organized crime in history", The Oxford Handbook of Organized Crime (Oxford University Press, 2014), pp. 53-95.

2 David E. Kaplan and Alec Dubro, Yakuza: Japan's Criminal Underworld (Berkeley, University of California Press, 2012), pp. 18-21.

3 Jason Sardell, "Economic origins of the mafia and patronage system in Sicily", BSc project, Worcester Polytechnic Institute, 13 March 2009

Fijnaut, "Searching for organized crime in history"

Michael Koutouzis and Pascale Perez, Atlas Mondial des

Drogues, Observatoire Géopolitique des Drogues (Paris,

Presses universitaires de France, 1996).

\section{Major transformation of organized crime in recent decades}

\section{Organized crime groups seize new opportunities}

Organized crime groups have always been resourceful in adapting to change. Anything from counterfeiting and fraud to kidnapping and trafficking in persons has been considered fair game. Probably the most visible example of this flexibility is the diversification that organized crime went through after the end of alcohol prohibition in the United States of America in 1933. Criminal groups that had exploited prohibition for profit in the 1920s went after new "business opportunities" in a wide range of potentially lucrative sectors in the 1930s.

Similarly, after a crackdown on organized crime groups in various parts of the world in the 1990s (the collapse of the Medellín and Cali cartels in Colombia, for example; the arrest of major organized crime bosses in the United States and Italy, etc.), new groups emerged with more diversified portfolios that included environmental crime, cybercrime, identity theft, the smuggling of migrants and money laundering. Many of the present-day activities of organized crime groups hardly existed in the early 1990s.

In some cases, organized crime groups have been able to profit from tighter regulatory systems. When a Government legislates to control, for example, hazardous waste, organized crime groups can step in and provide a cheaper service by circumventing these new standards. The same can be said of regulatory systems aimed at protecting wildlife, cultural heritage or intellectual property.

In general, the ability of organized crime groups to shift between illicit markets is illustrated by the fact that many of them already operate in more than one sector. In Mexico, for example, several major groups run activities spanning multiple business lines. ${ }^{6}$

6 Cameron H. Homes, Organized Crime in Mexico (Potomoc Books, University of Nebraska Press, 2014); George Philip and Suana Berruecos, eds., Mexico's Struggle for Public Security (Springer, June 2012); Jonathan D. Rosen and Roberto Zepeda, Organized Crime, Drug Trafficking, and Violence in Mexico: The Transition from Felipe Calerdón to Enrique Peña Nieto (Lexington Books, July 2016). 
In recent years, diversification among criminal groups, including drug traffickers, has increased rapidly. In 2013, the European Police Office (Europol) estimated that over 30 per cent of the organized crime groups operating in the European Union were involved in more than one crime area; the proportion was over 50 per cent for drug trafficking groups. By 2017, the figure had risen to 45 per cent for all groups and 65 per cent for groups involved in drug trafficking. Three quarters of drug trafficking groups were involved in trafficking more than one type of drug. Crimes frequently linked to drug trafficking in Europe include the counterfeiting of goods, trafficking in human beings, smuggling of migrants and trafficking in weapons. 7,8

\section{Structural transformation of organized crime groups}

Hierarchical structures have a major weakness: they can be easily dismantled when detected by the authorities. Some hierarchical crime groups have reshaped their structures in recent decades to become networked organizations. At the same time, smaller groups with looser hierarchies have begun to participate in international drug trafficking, often using new technologies to reduce the risk of detection.

Although most identified international organized crime groups in the European Union remain hierarchically organized, ${ }^{9}$ Europol suggests a trend away from vertical structures towards horizontal crime groups operating along a network organization model (cellular structure and less rigid or permanent hierarchies). ${ }^{10}$ Loose criminal networks represented 30-40 per cent of organized crime groups identified by Europol in 2017. ${ }^{11}$ Although they exist in all drug markets, loose criminal networks are particularly present in the trafficking of herbal cannabis and synthetic drugs, including new psychoactive substances (NPS). ${ }^{12}$ This type of network is often more nimble than other types and their members

\footnotetext{
7 Europol, SOCTA 2013: European Union Serious and Organised Crime Threat Assessment (The Hague, 2103).

8 Europol, SOCTA 2017: European Union: Serious and Organised Crime Threat Assessment (The Hague, 2017).

9 Ibid

10 SOCTA 2013.

11 SOCTA 2017.

12 Wouter Vanhove and others, Yilcan: Yield of Illicit Indoor Cannabis Plantations (Gent, Academia Press, 2012).
}

can communicate more rapidly, making them highly effective in delivering goods and harder to track down. ${ }^{13}, 14$ When individuals are targeted, the network can quickly regroup around new players, ${ }^{15}$ making them extremely resilient. ${ }^{16}$ The fragmentation of criminal markets with the emergence of small crime groups and even individual criminal entrepreneurs is especially pronounced in online activities, including the trafficking of drugs over the darknet. ${ }^{17}$ But drug trafficking is certainly not restricted to a single type of criminal group. Strongly hierarchical groups ${ }^{18}$ such as those in Mexico, Japan and to some extent the Russian Federation ${ }^{19}$ continue to be involved in the drug trade.

\section{Transformation of organized crime and drug markets through technology and logistics}

Organized crime groups are locked in fierce competition, not only with the authorities but also with their rivals. As is the case for any commercial activity with a strong field of competitors, crime groups wanting to stay ahead need to be first to deploy the latest technology.

13 Vy Le, "Organised crime typologies: structure, activities and conditions", Internal Journal of Criminology and Sociology, vol. 1 (Lifescience Global, Mississauga, Ontario, 2012), pp. 121-131

14 Frederick Desroches, "Research on upper level drug trafficking: a review", Journal of Drug Issues, vol. 37, No.4 (October 2007), p.833.

15 UNODC, Results of a Pilot Survey of Forty Selected Organized Criminal Groups in Sixteen Countries (September 2002).

16 Carlo Morselli, Inside criminal networks (2009); Toine Spapens, "Interaction between criminal groups and law enforcement: the case of ecstasy in the Netherlands" Global crime, vol. 12, No. 1 (2011), pp. 19-40; Paul A. C. Duijn, Victor Kashirin and Peter. M. A. Sloot, "The Relative Ineffectiveness of Criminal Network Disruption”, Scientific Reports, 4, 4238 (2014), p.1.

17 SOCTA 2017.

18 Le, "Organised crime typologies: structure, activities and conditions".

19 In the case of Russian organized crime groups the organizational structure is hierarchical though rather decentralized as groups are often composed of separate quasi-autonomous "brigades" operating more or less independently from each other even though they tend to pool their resources (Frederico Varese, professor of criminology at the University of Oxford, quoted in "Fortune 5: The biggest organized crime groups in the world", Fortune (September 14, 2014). Available at http://fortune.com/2014/09/14/biggest-organizedcrime-groups-in-the-world/) 
Organized crime groups have long focused on speeding up transportation of drugs by using ships, containers, aircraft or even by manufacturing their own semi-submersible vessels. As a result, they have been able to transport ever larger amounts of drugs across the globe. ${ }^{20}$

The mobile communications revolution has offered new risk-averse opportunities. Rather than engaging in personal contact with clients, drug dealers can now use low-level runners to collect cash before letting the customer know by text message where to collect their drugs. Even when dealers get caught, they are rarely in possession of anything more than a small quantity of any particular drug, clearly reducing their "business risk". ${ }^{21}$ Added to this, dealers can use encryption software to protect their communications and data - a problem for law enforcement authorities that is compounded by the growing popularity of native encryption on mobile devices. ${ }^{22}$ As a result, a list of potential clients' telephone numbers saved on a cell phone or a SIM card is now a valuable asset that can even be traded among crime groups.

More recently, reports suggest that drug trafficking gangs have been hacking into drone management systems used in the United States to police the Mexican border ${ }^{23}$ and systems used by the port authorities in Antwerp to track containers. ${ }^{24}$ Europol has highlighted the emerging phenomenon of criminal groups hiring specialist hackers and expects such activities to grow in importance. ${ }^{25}$

20 Damián Zaitch, Trafficking Cocaine: Colombian Drug Entrepreneurs in the Netherlands, Studies of organized crime, vol. 1 (The Hague, Kluwer Law International, 2002).

21 Agnés Cadet-Tärou and others, "Substances psychoactives, usagers et marchés: les tendances récentes (2015-2016)”, Tendances, vol. 8, No. 115 (December 2016).

22 Europol, IOACTA 2016: Internet Organized Crime Threat Assessment (The Hague, 2016).

23 "US border patrol drones hacked by drug cartels", 3 January 2016. Available at www.hackread.com/us-borderpatrol-drones-hacked-by-drug-cartels/

24 "To move drugs, traffickers are hacking shipping containers", 21 October 2013. Available at https://motherboard. vice.com/en_us/article/how-traffickers-hack-shippingcontainers-to-move-drugs.

25 "Police warning after drug traffickers' cyber-attack", 16 October 2013, BBC News. Available at http://www.bbc.com/ news/world-europe-24539417.
Still a niche market in the global context but with strong growth potential, the darknet is an encrypted network where users can anonymously exchange goods and services, both legal and proscribed. Darknet users get drugs posted to them after paying in a cryptocurrency such as bitcoin. Its anonymity reduces the risk of arrest for both dealers and users, and also eliminates other pitfalls associated with buying drugs, such as the possibility of falling victim to other forms of crime in neighbourhoods where drug dealing is rife. ${ }^{26}$

For the time being, the darknet accounts for only a small percentage of drug sales. Typical buyers are recreational drug users who mostly purchase cannabis, ecstasy, cocaine, various types of hallucinogen and NPS. They are less prone to ordering heroin and methamphetamine. ${ }^{27}$ But drug purchases on the darknet are growing rapidly in some countries 28 and its more direct process cuts several links out of the supply chain. ${ }^{29}$ A study of so-called "cryptomarkets" concluded that nearly a quarter of their overall revenue, both in September 2013 and in January 2016, was generated by transactions greater than $\$ 1,000$, suggesting that some purchases are intended for offline distribution. ${ }^{30}$

While drug trafficking over the darknet is still relatively small in scale and concentrated in developed countries, it is fast growing and has the potential to significantly reduce the need for the large, staffintensive, drug distribution networks that have been operating for decades in cities across the globe. If this were to happen, the results would be difficult to predict. For instance, the current cultivation areas of plant-based drugs would be unlikely to change. But at the distribution level, street dealers could end up in violent competition for their dwindling client base, or they may look for alternative ways of making

26 Cadet-Taïrou and others, "Substances psychoactives, usagers et marchés: les tendances récentes".

27 Global Drug Survey 2016 and Global Drug Survey 2015. Available at www.globaldrugsurvey.com.

28 Ibid.

29 James Martin. "Lost on the Silk Road: online drug distribution and the "cryptomarket". Criminology and Criminal Justice, vol. 14, No. 3 (2014), p.362.

30 Kristy Kruithof and others, Internet-facilitated Drugs Trade: An Analysis of the Size, Scope and the Role of the Netherlands, Research Report Series (Santa Monica, California, Rand Corporation, 2016). 
money. While violence in the core drug business (the supplier-customer relationship) might be reduced with the spread of anonymous drug purchases, it is less clear whether this will ultimately result in more or less crime.

\section{Evolution of links between organized crime and drug trafficking}

Most of the increase and involvement of organized crime groups in drug trafficking worldwide occurred after the Second World War. ${ }^{31}$ While there were still some individuals involved in the illicit drug trade in the 1960s and 1970s, groups became dominant in the 1980s, when business became increasingly cross-border and complex.

The 1990s witnessed a new phase with the powerful Medellín drug cartel collapsing in 1993 and the Cali cartel being taken out in 1995 , eliminating the groups that had controlled much of the international cocaine business. ${ }^{32}$ The fall of the Colombian cartels heralded a series of changes in the drug trafficking scene during the 1990s, including the emergence of smaller groups. They turned out to be efficient in trafficking drugs but were less of an immediate threat to the State as such.

In Myanmar, the Mong Tai Army had controlled much of the production and export of heroin to countries in East and South-East Asia, ${ }^{33}$ prior to being dissolved in 1996. ${ }^{34}$ This disrupted the supply chain it had established through Hong Kong, China and Taiwan Province of China and on to the markets in North America. ${ }^{35}$ In destination and

31 David F. Musto, The American Disease - Origins of Narcotic Control (Oxford University Press, 1987).

32 Francisco E. Thoumi, Debates y Paradigmas de las Poliiticas de Drogas en el Mundo y los Desafíos para Colombia (Bogotá, Academia Colombiana de Ciencias Económicas, 2015).

33 United Nations office for Drug Control and Prevention (ODCCP), "Main centres of illicit opium production - Myanmar" in ODCCP Studies on Drugs and Crime, Global Illicit Drug Trends 2001, pp. 44-59.

34 Michael E. Brown and Sumit Ganguly, eds., Government Policies and Ethnic Relations in Asia and the Pacific, CISA Studies in International Security, in cooperation with the Pacific Basin Research Center (London, 1997); Global Security.org, Mong Tai Army (MTA). Available at www. globalsecurity.org/military/world/para/sua.htm; Mong Tai Army. Available at www.revolvy.com/main/index. php?s=Mong\%20Tai\%20Army.

35 Koutouzis and Perez, Atlas Mondial des Drogues; Paul B. States, Global Habit - The Drug Problem in a Borderless transit markets, several so-called "big bosses" of organized crime in Italy and the United States were also arrested during that decade. They had previously controlled much of the trafficking of drugs in their respective countries. ${ }^{36}$ After these disruptions, smaller groups emerged, some of which were spinoffs from the dismantled groups. Many of them continued to rely on the drug trade, even though the overall importance of drugs appears to have started to decline as organized crime groups discovered new lucrative and less risky business opportunities.

Similarly, the emergence of new organized crime groups from the successor States of the former Soviet Union and other transition countries in Eastern Europe in the 1990s seemed to presage the decline in significance of the drug trade for organized crime groups. These new groups were never primarily focused on drug trafficking. ${ }^{37}$ However, a UNODC study with a global focus suggested that by 2002 half of the 40 criminal groups operating in the 16 countries investigated counted illicit drugs as their main or core activity. ${ }^{38}$

\section{Drugs remain an important market for organized crime}

Despite the transformations in recent decades and a trend towards crime diversification, the drug market continues to play a key role in organized crime activities. In Europe, illicit drugs not only constitute the single largest organized crime market, ${ }^{39}$ but also a market that shows a high degree of both collaboration and competition between organized crime groups across national, linguistic and ethnic divisions. ${ }^{40}$

World, The Brookings institution (Washington D.C., 1996); David Amoruso, "The Golden Triangle: How triads cornered the heroin market” (16 June 2016). Available at http://gangstersinc.ning.com/profiles/blogs/the-goldentriangle-how-triads-cornered-the-heroin-market.

36 Koutouzis and Perez, Atlas Mondial des Drogues.

37 Vadim Volkov, "The Russian mafia; rise and extinction", The Oxford Handbook of Organized Crime, Letizia Paoli, ed. (Oxford University Press, 2014), pp. 159-176.

38 UNODC, Results of a Pilot Survey of Forty Selected Organized Criminal Groups in Sixteen Countries (September 2002).

39 SOCTA 2013

40 Mangai Natarajan, Marco Zanella and Christopher Yu, "Classifying the variety of drug trafficking organizations", 
FIG. 1 Importance of organized crime groups, European Union

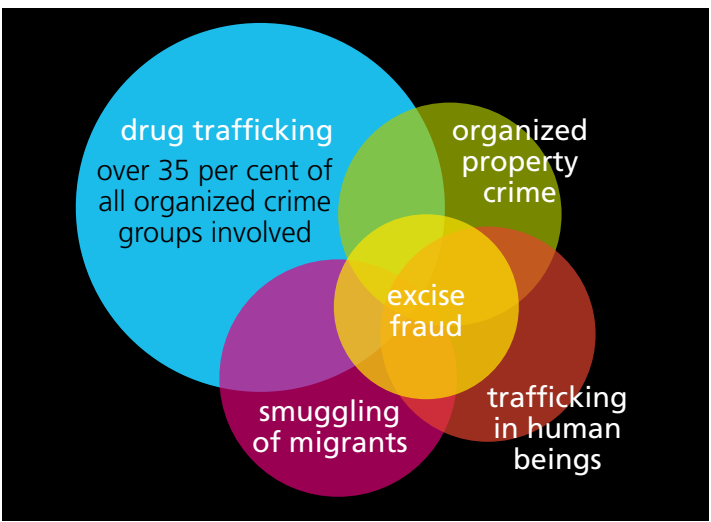

Source: UNODC, adapted from Europol, SOCTA 2017

Europol identified some 5,000 international organized crime groups operating in the European Union in 2017 , over 35 per cent of which were involved in drug trafficking - more than in property crime, the smuggling of migrants, trafficking in human beings, excise fraud or any other illicit activity. ${ }^{41}$ Compared with organized crime groups operating in other crime areas, such as financial and economic crime, property crime and counterfeiting, organized crime groups involved in drug trafficking tend to be larger. ${ }^{42}$

As a consequence of globalization and cross-border networking, Europol concluded that non-European Union crime groups involved in the drug trade in Europe are nowadays made up of citizens from a large number of countries; most likely countries in Latin America, the former Soviet Union, Afghanistan, Pakistan and countries in East Asia and in North Africa. Seventy per cent of organized crime groups in Europe are composed of members of many different nationalities. ${ }^{43}$

\section{State responses to drug trafficking groups}

The emergence of powerful and politically influential cross-border drug trafficking organizations in the 1980s prompted national Governments to commit to international legal obligations to fight such criminal activities.

One of the key instruments they adopted was the United Nations Convention against Illicit Traffic in Narcotic Drugs and Psychotropic Substances, 1988, which specifically warned of "the links between illicit traffic and other related organized criminal activities

\section{TABLE 1 Organized crime groups active in illicit drug markets in Europe}

\begin{tabular}{|c|c|c|}
\hline & $\begin{array}{l}\text { Strong evidence of involvement of } \\
\text { organized crime groups from } \\
\text { specific countries/regions }\end{array}$ & $\begin{array}{l}\text { Limited evidence of involvement of organized } \\
\text { crime groups from specific countries/regions }\end{array}$ \\
\hline Heroin & Albanian, Balkan, Turkish, African & $\begin{array}{l}\text { Bulgarian, Romanian, other eastern European, British, } \\
\text { Dutch, Italian mafias, other Italian, Lithuanian, motorcycle } \\
\text { gangs, Middle Eastern, other Asian, North African }\end{array}$ \\
\hline Cocaine & $\begin{array}{l}\text { Colombian, African, Albanian, } \\
\text { Italian ('Ndrangheta), Spanish }\end{array}$ & $\begin{array}{l}\text { British, Finnish, French, other Italian, motorcycle gangs, } \\
\text { other western European, Balkan, Bulgarian, Romanian, } \\
\text { Russian/Georgian, Mexican, North African, } \\
\text { South American }\end{array}$ \\
\hline Cannabis & $\begin{array}{l}\text { Albanian, Chinese, Dutch, } \\
\text { North African, other Asian, Spanish }\end{array}$ & $\begin{array}{l}\text { African, Russian/Georgian, Turkish, Italian mafias, British, } \\
\text { Finnish, French, Irish, motorcycle gangs }\end{array}$ \\
\hline $\begin{array}{l}\text { Other illicit } \\
\text { drugs }\end{array}$ & $\begin{array}{l}\text { British, Dutch, Lithuanian, } \\
\text { other eastern European }\end{array}$ & $\begin{array}{l}\text { British, Finnish, motorcycle gangs, other western } \\
\text { European, Albanian, Russian/Georgian, Turkish, Chinese, } \\
\text { other Asian }\end{array}$ \\
\hline
\end{tabular}

Source: Ernesto U. Savona and Michele Riccardi, eds., From Illegal Markets to Legitimate Businesses: the Portfolio of Organised Crime in Europe, Final Report of Project OCP - Organised Crime Portfolio (Trento, Transcrime, Università degli Studi di Trento, 2015).

\footnotetext{
Journal of Drug Issues (2015), 409-430; François Farcy,

"Renseignement criminel et lutte contre la criminalité organisée en Belgique", Revue Française de Criminologie et de Droit Pénal, No. 4, (2015), pp 3-40. 


\section{Nexus between organized crime and drugs in Germany}

Some 37 per cent of prosecutions against organized crime groups in Germany in 2015 were linked to groups involved in drug trafficking, according to government data. Europol estimated a similar proportion for the European Union as a whole (more than 35 per cent in 2017). ${ }^{a}$

Distribution of types of organized crime activities in Germany (per cent), based on number of legal proceedings against organized crime groups, $2015^{*}$

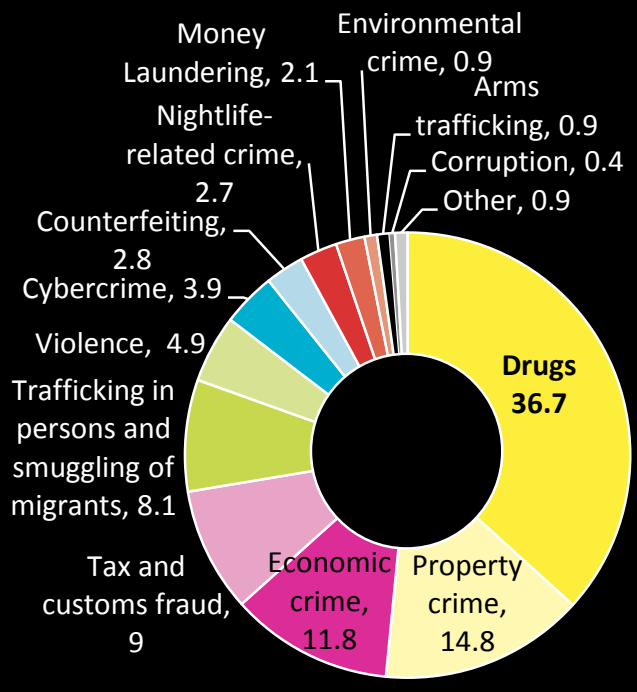

* $N=566$ legal proceedings against organized crime groups, of which 205 were primarily involved in drug trafficking. The total number of suspects among those organized crime groups amounted to 8,675 persons in $2015 \mathrm{~s}$.

Source: Bundeskriminalamt (BKA), "Organisierte Kriminalität: Bundeslagebild, 2015

Estimated at 0.7 per cent of GDP in 2010, overall income generated by organized crime in Germany seemed to be below the European Union average, estimated at 0.9 per cent. ${ }^{b}$

The proportion of organized crime groups involved in drug trafficking in Germany declined between 2009-2014, though it increased again in 2015 as details of prosecutions suggest. In recent years, other crime areas have been growing in importance: property crime (from 12 per cent in 2010 to 15 per cent in 2015), cybercrime (from 0.7 per cent in 2010 to 4 per cent in 2015) and trafficking in persons and smuggling of migrants (from 6 per cent in 2010 to 8 per cent in 2015). c While this trend reflects the diversification of activities and areas in which organized crime is involved, it may also reflect the increasing attention of law enforcement authorities to other crime areas.

\section{a SOCTA 2017.}

b Ernesto U. Savona and Michele Riccardi, eds., From Illegal Markets to Legitimate Businesses: the Portfolio of Organised Crime in Europe, Final Report of Project OCP - Organised Crime Portfolio (Trento, Transcrime, Università degli Studi di Trento, 2015) p. 36.
Proportion of prosecuted groups involved in illicit drugs in overall prosecuted organized crime groups, Germany, 2009-2015*

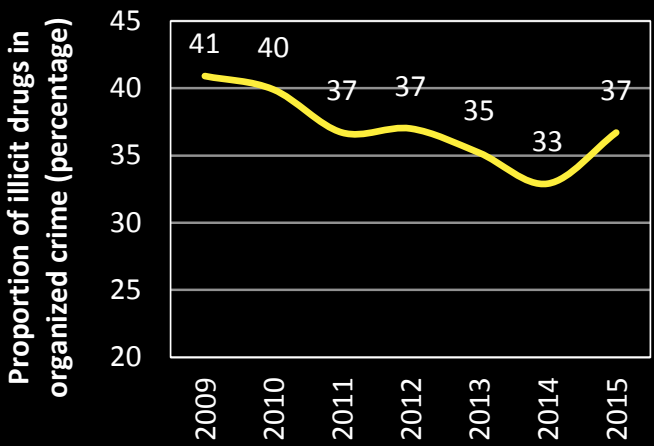

* The total number of prosecutions against organized crime groups has remained relatively stable in recent years: 579 in 2009 and 566 in 2015

Source: BKA, "Organisierte Kriminalität: Bundeslagebild, 2015"

Proportion of drug offences in all reported offences and in all prosecutions related to organized crime groups, Germany, 2014 and 2015

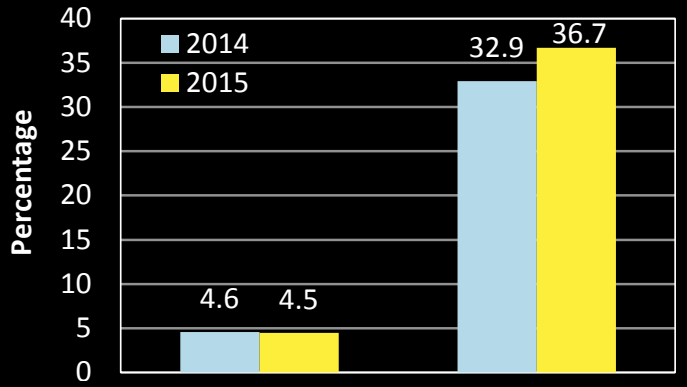

Proportion of all offences

Proportion of proceedings related to organized crime

Source: BKA, "Organisierte Kriminalität, Bundeslagebild 2015" (and 2014); BKA, Polizeiliche Kriminalstatistik: Bundesrepublick Deutschland - Jahrbuch 2015 (and 2014).

Nonetheless, drug trafficking has continued to be the main activity shared by organized crime groups in Germany. The importance of illicit drugs in prosecution cases of organized crime groups remains far higher (eight times higher in 2015) than in overall reported offences. ${ }^{d}$

c BKA, "Organisierte Kriminalität, Bundeslagebild 2015 and $2010 "$. Available at www.bka.de.

d BKA, Polizeiliche Kriminalstatistik: Bundesrepublick Deutschland - Jahrbuch 2014, 62nd ed. (Wiesbaden, Kriminalistisches Institut, 2014). 
which undermine the legitimate economies and threaten the stability, security and sovereignty of States". Governments agreed on a broad range of measures to fight drug trafficking, including extradition, confiscation of proceeds, mutual legal assistance, precursor control, anti-money laundering measures and controlled deliveries.

The 1988 Convention also stipulated that serious offences such as the production, manufacture, transport, sale, importation, exportation of drugs 44 would be extraditable, ending years of impunity and curtailing the ability of crime bosses to continue their operations from behind the walls of local prisons. In the Americas, this may have prompted organized crime groups to adjust their strategies. Rather than sending drugs straight to lucrative final destinations where extradition treaties were enforced, they may have begun to make use of transit countries from where extradition was less likely, even if prices were lower and profits were smaller. This changed international drug trafficking flows as well as the power structures of organized crime groups. Colombian groups, for example, may have given up influence, enabling Mexican organized crime groups to fill the void and develop into powerful drug cartels. The change also may have created new opportunities for smaller groups to get involved, expanding the chain of drug trafficking in transit countries, notably in Central America and later in Africa, where drug trafficking groups brought instability and violence.

Successes in the fight against drug trafficking, partly prompted by improved international cooperation, brought rising levels of risk and motivated several organized crime groups to look for alternative opportunities that would attract less attention from authorities. Against this backdrop, a new international tool was devised to fight organized crime. In 2000, the United Nations Convention against Transnational Organized Crime, also called the Palermo Convention, was signed. Signatories agreed to criminalize participation in organized crime groups,

44 Covered by article 3, para. 1, of the Convention, this includes activities such as production, manufacture, transport, sale, importation, exportation of drugs contrary to the 1961 or the 1971 conventions, unlawful distribution of precursor chemicals as well as money laundering and related activities; not included are offences related to the purchase, possession or cultivation of drugs for personal consumption. money laundering, corruption and obstruction of justice. The Convention extended the framework for legal assistance, law enforcement cooperation and extradition from drug trafficking to all forms of organized crime.

In parallel, efforts increased to deal with the drug problem, not only from the supply but also from the demand side. The 1998 Political Declaration and its Action Plans, the 2009 Political Declaration and Plan of Action, as well as the Outcome document of the 2016 special session of the United Nations General Assembly on the world drug problem, stressed the importance of demand reduction efforts as part of a balanced approach to address the drug problem.

National Governments have also sought to counter the technology harnessed by drug trafficking organizations by updating their standards on the acceptance of electronic evidence, training their staff in the detection and use of this kind of evidence, and introducing new strategies specifically targeting the use of social and electronic media by drug traffickers.

However, many Governments seem to have started shifting their focus from drug control to a broader range of criminal activities. The illicit drug trade is increasingly seen as one crime typology among the many. Budgets have been rising for fighting terrorism, trafficking in persons, cybercrime, money laundering, corruption and various other forms of economic crime. In parallel, international assistance for anti-narcotics activities and alternative development has declined; remarkable because overall development assistance has continued to increase since 2009.45

\section{B. DRUG PROCEEDS AND ILLICIT FINANCIAL FLOWS}

Billions of dollars flow through the hands of drug trafficking organizations each year, and what they do with that money can have a huge impact on local and wider economies. They might smuggle cash out of their home country, buy or build real estate, invest in restaurants and casinos for money laundering No. E.16.XI.7). 


\section{Sustainable development goals: target 16.4}

By 2030, significantly reduce illicit financial and arms flows, strengthen the recovery and return of stolen assets and combat all forms of organized crime.

The international community is currently developing indicators to measure the reduction in illicit financial flows, including those related to the illicit drug sector.

Measurement concepts: from drug proceeds to illicit financial flows

\section{5}

\section{DRUG PROCEEDS}

Gross profit of drugs = drug proceeds - cost of drugs Net profit of drugs = gross profit - trafficking costs *

Profits available for laundering $=$ net profit - living expenses of traffickers**

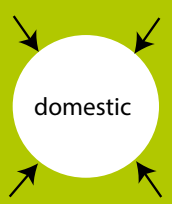

* Transportation costs, intermediaries, bribes, etc.

** Living expenses, luxury goods, cars, etc.

\section{What the United Nations says}

The proceeds of crime are defined in the United Nations Convention against Transnational Organized Crime, 2000 as well as in the United Nations Convention against Corruption, 2003 as "any property derived from or obtained, directly or indirectly, through the commission of an offence".

This was previously described in the United Nations Convention against Illicit Traffic in Narcotic Drugs and Psychotropic Substances, 1988 as "any property derived from or obtained, directly or indirectly, through the commission of an offence established in accordance with article 3, paragraph 1." purposes, or stash their profits in offshore financial centres. Depending on the method they choose, property prices can be distorted, unfair competition created, licit businesses crowded out, corruption bolstered and the climate to attract international investment spoilt, ultimately eroding rule of law and economic stability.

This section assesses how much money drug-related crime generates and describes how trafficking groups channel their money into the wider economy, particularly when they send money abroad, in which case it is termed "illicit financial flows".

Understanding these processes is a vital component in the fight against both financial and drug-related crime.

\section{Proceeds of drug crime}

Measuring the financial significance of illicit activities enables the comparison of criminal activities across sectors. The term "proceeds" is equivalent to "sales", "turnover" and "revenue". In the case of drugs, it represents the quantity of drugs sold multiplied by respective retail prices.

Some recent global estimates suggest that the proceeds of drug sales accounted for slightly more than one quarter of overall revenues of transnational organized crime groups in 2014, with a maximum range from around one fifth to one third of such revenues. In recent years, drug-related income seems to have represented the second largest source of income - after counterfeiting of a broad range of goods - of transnational organized crime groups at the global level. ${ }^{46}$

Drug proceeds in industrialized countries

Drug money was the second largest source of criminal revenue in the United States, the United

46 This was based on drug trafficking estimates of $\$ 426$ to $\$ 652$ billion out of a total transnational organized crime income of $\$ 1.6$ trillion to $\$ 2.2$ trillion in 2014 (Channing May, "Transnational crime and the developing world", Global Financial Integrity (Washington D.C., March 2017). 
TABLE 2 Proceeds of illicit drug sales and other crimes in selected industrialized countries, expressed as proportion of gross domestic product

\begin{tabular}{|c|c|c|c|c|}
\hline & \multicolumn{3}{|c|}{ As a percentage of gross domestic product } \\
\hline & $\begin{array}{l}\text { Year of } \\
\text { estimate }\end{array}$ & Drugs & $\begin{array}{c}\text { Total crime, } \\
\text { excluding tax evasion }\end{array}$ & $\begin{array}{l}\text { Total crime, } \\
\text { including tax evasion }\end{array}$ \\
\hline United States & 2000 & $0.7 \%$ & $2.3 \%$ & $8.0 \%$ \\
\hline United Kingdom & $1996 / 2003 / 04$ & $0.5 \%$ & $1.2 \%$ a & n.a. \\
\hline Australia & 2003 & $0.3 \%$ & $1.5 \%$ & n.a. \\
\hline Netherlands & 2003 & $0.4 \%$ & $1.7 \%$ b & $3.5 \%$ \\
\hline Germany & 2007 & $0.4 \%$ & $1.3 \%$ & $2.3 \%$ \\
\hline Italy & 2009 & $0.7 \%$ & $7.7 \%$ & n.a. \\
\hline $\begin{array}{l}\text { Unweighted } \\
\text { average }\end{array}$ & & $\begin{array}{c}\mathbf{0 . 5 \%} \\
(0.4 \%-0.6 \%)\end{array}$ & $\begin{array}{c}2.6 \% \\
(0.6 \%-4.6 \%)\end{array}$ & $\begin{array}{c}\mathbf{4 . 6 \%} \\
(2.2 \%-7.0 \%)\end{array}$ \\
\hline $\begin{array}{l}\text { Weighted } \\
\text { average c }\end{array}$ & & $\begin{array}{c}\mathbf{0 . 6 \%} \\
(0.5 \%-0.7 \%)\end{array}$ & $\begin{array}{c}2.5 \% \\
(0.5 \%-4.5 \%)\end{array}$ & $\begin{array}{c}\mathbf{5 . 3} \% \\
(2.9 \%-7.7 \%)\end{array}$ \\
\hline
\end{tabular}

Sources: UNODC, Estimating Illicit Financial Flows Resulting from Drug Trafficking and Other Transnational Organized Crime, Research report (October 2011). Based on: Peter Reuter and Edwin M. Truman, "Chasing Dirty Money - the Fight against Money Laundering" (Washington D.C., 2004); ONDCP, What America's Users Spend on Illegal Drugs (Washington D.C., December 2001); Chris Groom and Tom Davies, "Developing a Methodology for Measuring Illegal Activity for the UK National Accounts", Economic Trends, No. 536, July 1998, pp. 33-71; Stephen Pudney, Celia Badillo, Mark Bryan, Jon Burton, Gabriella Conti, Maria lacovou, "Estimating the size of the UK illicit drug market", in Home Office, "Measuring different aspects of problem drug use: methodological developments", Home Office Online Report 16/06; Updates from an original paper undertaken by John Walker for the Australian Institute of Criminology in 1992, quoted in Brigitte Unger, The Scale and Impacts of Money Laundering (Cheltenham, Edward Elgar Publishing Company, 2007); FATF, Mutual Evaluation Report, February 2010 and International Monetary Fund, March 2010; International Monetary Fund, "Germany: Detailed Assessment Report on Anti-Money Laundering and Combating the Financing of Terrorism", IMF Country Report No. 10/78 (Washington D.C., February 2010). Statistisches Bundesamt, Wiesbaden; Consiglio Italiano per le Scienze Sociali, II mercato illecito and SOS Impresa, XII Rapporto - Le mani della criminalità sulle imprese (Rome, SOS, 27 January 2010).

a Partial estimate of a limited number of selected crimes.

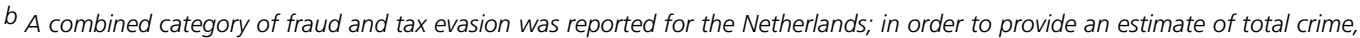
excluding tax evasion, it was assumed that the same breakdown existed in the Netherlands as in Germany.

c Country results weighted by their gross domestic product in 2009.

Kingdom of Great Britain and Northern Ireland, the Netherlands and Italy, according to estimates dating from 2000-2009 compiled by UNODC. 47 All other criminal activity was dwarfed in terms of revenue by tax evasion, according to the study, which also included data from Australia and Germany. If tax evasion is excluded, drugs accounted for between one fifth and one quarter of the total proceeds of crime in the six countries combined over this period, the data suggest. With tax evasion included, drugs still account for roughly 10 per cent of the total proceeds of crime.

47 UNODC, Estimating Illicit Financial Flows Resulting from Drug Trafficking and Other Transnational Organized Crime, Research report (October 2011), pp. 70-91.
In the European Union, the 2013 drug market is valued at approximately 24.3 billion euros a year. ${ }^{48}$ According to studies that valued the drug market in 2010 , as a percentage of economic output, drug sales were less important in the European Union than in the United States. In 2010, spending on drugs amounted to 0.23 per cent (27.7 billion euros) of the gross domestic product (GDP) of the European Union, ${ }^{49}$ compared with 0.7 per cent ( $\$ 109$ billion) in the United States. 50

48 Range: 21-31 billion euros (European Monitoring Centre for Drugs and Drug Addiction (EMCDDA), European Drug Report, Trends and Developments (Lisbon, 2016)).

49 Savona and Riccardi, eds., From Illegal Markets to Legitimate Businesses: the Portfolio of Organised Crime in Europe.

50 Beau Kilmer and others, What Americas Users Spend on Illegal Drugs: 2000-2010, Research Reports Series, document No. RR-534-ONDCP (Santa Monica, California, Rand Corporation, 2014). 
$\begin{array}{ll}\text { TABLE } 3 & \text { Revenues from illicit markets per year (billions of euros) }\end{array}$

\begin{tabular}{|c|c|c|}
\hline Illicit market & $\begin{array}{l}\text { Seven western } \\
\text { European countries }{ }^{a}\end{array}$ & $\begin{array}{l}\text { European } \\
\text { Union }\end{array}$ \\
\hline Illicit drugs & 20.2 & 27.7 \\
\hline Trafficking in human beings & \multicolumn{2}{|c|}{ Estimate available in only a few European countries } \\
\hline Illicit trafficking in firearms & - & 0.4 \\
\hline Illicit trade in tobacco products & 5.2 & 9.4 \\
\hline Counterfeiting & 21.6 & 42.7 \\
\hline Illegal gambling & \multicolumn{2}{|c|}{ Estimate available in only a few European countries } \\
\hline Extortion racketeering & \multicolumn{2}{|c|}{ Estimate available in only a few European countries } \\
\hline Usury & \multicolumn{2}{|c|}{ Estimate available in only a few European countries } \\
\hline Missing trade Intra-community fraud & 16.9 & 29.3 \\
\hline Cargo theft & 0.36 & 0.42 \\
\hline Total & 64.2 & 109.9 \\
\hline
\end{tabular}

Source: Savona and Riccardi, eds., From Illegal Markets to Legitimate Businesses: the Portfolio of Organised Crime in Europe.

a Finland, France, Ireland, Italy, Netherlands, Spain, United Kingdom.

TABLE 4 Illicit drug retail sales in constant currency units and expressed as a percentage of gross domestic product in the United States and 21 European Union countries

\begin{tabular}{|c|c|c|c|c|c|c|c|c|}
\hline & & 1988 & 1990 & 1995 & 2000 & 2005 & 2010 & 2015 \\
\hline \multicolumn{9}{|c|}{ Retail drug sales in constant currency units } \\
\hline United States & $\begin{array}{l}\text { In constant } 2010 \$ \\
\text { (billions) }\end{array}$ & 195 & 146 & 95 & 108 & 119 & 109 & .. \\
\hline $\begin{array}{l}21 \text { European Union } \\
\text { countries* }\end{array}$ & $\begin{array}{l}\text { In constant } 2010 \text { euros } \\
\text { (billions) }\end{array}$ & .. & .. & 13.1 & 15.3 & 19.2 & 19.2 & 18.0 \\
\hline
\end{tabular}

Retail drug sales as a proportion of gross domestic product

\begin{tabular}{|c|c|c|c|c|c|c|c|c|}
\hline United States & $\%$ of GDP & 2.22 & 1.57 & 0.90 & 0.85 & 0.83 & 0.74 & ... \\
\hline $\begin{array}{l}21 \text { European Union } \\
\text { countries* }\end{array}$ & $\%$ of GDP & 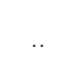 & . & 0.62 & 0.49 & 0.37 & 0.34 & 0.32 \\
\hline
\end{tabular}

Sources: UNODC calculations, based on: Kilmer and others, What Americas Users Spend on Illegal Drugs: 2000-2010; World Bank, World Development Indicators; Eurostat, Eurostat database. Available at http://ec.europa.eu/eurostat/data/database.

a Austria, Belgium, Bulgaria, Czechia, Cyprus, Denmark, Estonia, Finland, Greece, Hungary, Ireland, Latvia, Lithuania, Luxembourg, Portugal, Romania, Slovenia, Slovakia, Spain, Sweden, United Kingdom.

Note: Two dots indicate that data are not available.

The 2010 estimate in the European Union was equivalent to roughly 25 per cent of overall criminal proceeds, making drugs the third largest source of income from organized crime there, after tax fraud and counterfeiting. Excluding tax fraud, drugs accounted for 34 per cent of total revenues of organized crime in the European Union. ${ }^{51}$

51 Savona and Riccardi, eds., From Illegal Markets to Legitimate Businesses: the Portfolio of Organised Crime in Europe.
Accounting for 42 per cent of the total proceeds of organized crime after tax fraud was excluded, 52 drugs were even more important in seven western European countries - Finland, France, Ireland, Italy, the Netherlands, Spain, United Kingdom — when taken together.

According to the statistical office of the European Union, Eurostat, European households in 21 European member states spent a total of 21 billion euros

52 Ibid. 
(0.3 per cent of GDP) on drugs in 2015. This estimate, based on figures from countries representing around half of the total GDP of the European Union, 53 showed a decline compared with 1995 , when spending was estimated at 0.6 per cent of GDP. ${ }^{54}$ A similar decline has also been observed in the United States in the past two decades; illicit drug sales fell from 1.6 per cent of GDP in 1990 to 0.7 per cent in 2010.

Drug sales expressed in constant currency units have fallen in the United States since the late 1980s, but in Europe they have increased over the past two decades. This suggests that the marked decline in the proportion of drug sales to GDP in Europe is the result of stronger growth of GDP in other sectors rather than a declining drug market.

Drug sales increased in the 21 European Union countries by some 50 per cent from 1995 to 2008, the year when the global financial crisis hit. From 2008 to 2015, sales declined by some 10 per cent. Drug sales in both Spain and the United Kingdom (0.6 and 0.4 per cent, respectively, of GDP) declined by 15 per cent over the period 2008-2015. The largest decline was reported by Cyprus. This could suggest a link between drug sales and the financial crisis. However, estimates from Greece show a strong increase in drug sales over the period 2008-2015 (31 per cent), suggesting that the financial crisis was not necessarily the determining factor for explaining changes in the drug markets. Meanwhile, countries including Austria, Finland, Lithuania, Luxembourg, Portugal and Sweden all recorded drug sales as less than 0.1 per cent of GDP in 2015.55

\section{Drug proceeds in major drug-producing countries}

In contrast to the European Union or the United States, where drug markets represent a very small proportion of the total economy, in present-day Afghanistan and in Colombia at the turn of the millennium, the situation was very different.

\footnotetext{
53 All European Union countries with the exception of Croatia, France, Germany, Italy, Malta, the Netherlands and Poland.

54 Eurostat database. Available at http://ec.europa.eu/eurostat/ data/database.

55 Ibid.
}

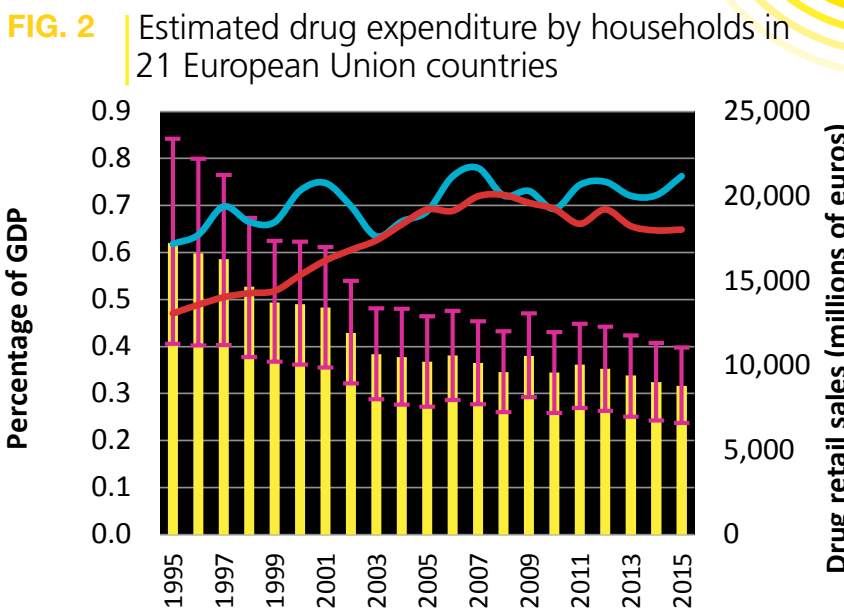

Drug purchases as a percentage of GDP (21 European Union countries), including 95 per cent confidence-interval

\section{Drug purchases in 21 European Union countries in current euros}

\section{Drug purchases in 21 European Union countries in constant euros}

\section{Source: EUROSTAT.}

In Afghanistan, the net value of opiate exports fluctuated between 7 per cent and 16 per cent of GDP over the period 2011-2016, according to UNODC estimates. 56

In Colombia, according to some studies, the illicit income from all crime activities (including drugs) has fallen consistently for almost two decades. The decline in drug-related income in Colombia went in parallel with an overall reduction in the area under coca cultivation - by roughly 70 per cent over the period 2000-2013 — as well as strong declines in opium production. 57

\section{Laundering drug profits}

Estimates suggest that well over half of the gross profits generated by the drug trade are channelled into money laundering.

In the late 1980s, the Financial Action Task Force (FATF) assumed that between two thirds and 70 per cent of drug money was laundered. ${ }^{58}$ The FATF

\footnotetext{
56 Afghanistan, Ministry of Counter Narcotics (MCN) and UNODC, Sustainable Development in an Opium Production Environment - Afghanistan Opium Survey Report 2016 (Vienna, 2017) and previous years.

57 World Drug Report 2016 and previous years.

58 United Nations International Drug Control Programme
} 
TABLE 5 Financial Action Task Force estimates of global amounts laundered in the late 1980s

Estimate of drug sales in key markets (1988)

As a percentage of global GDP (1988)

Assumed proportion that is laundered

Estimate of amounts laundered related to drugs

Proportion of global GDP (1988)

Estimated proportion of drugs in total amounts laundered

Estimated total amounts laundered in 1988

As a percentage of global GDP
$\$ 124$ billion

$0.8 \%$

$2 / 3-70 \%$

$\$ 85$ billion

$0.5 \%$ of GDP

$25 \%$

$\$ 340$ billion

$2.0 \%$ of GDP

Source: Economic and Social Consequences of Drug Abuse and Illicit Trafficking, UNDCP Technical Series No. 6, Vienna 1998; International Monetary Fund, Financial System Abuse, Financial Crime and Money Laundering-Background Paper, February 2001.

study, one of the first to make such an estimate, based its figures on interviews with experts in the field.

The conclusions broadly tally with a UNODC review of the literature from Australia, the Netherlands and the United States in $2011.5^{59}$ Those studies used different methodologies, but the overall average proportion of money available for laundering out of crime proceeds was roughly 70 per cent, with reported figures ranging from 39 per cent to 83 per cent. ${ }^{60}$ Most of this money would be laundered though a small proportion of the cash may also be hidden and stocked for use at a later stage.

(UNDCP), Economic and Social Consequences of Drug Abuse and Illicit Trafficking, UNDCP Technical Series No. 6 (Vienna, 1998); International Monetary Fund (IMF), "Financial system abuse, financial crime and money laundering - background paper” (12 February 2001).

59 UNODC, Estimating Illicit Financial Flows Resulting from Drug Trafficking and Other Transnational Organized Crime, Research report (October 2011), pp. 70-91.

60 John Walker, "Estimates of the extent of money laundering in and through Australia," paper prepared for Australian Transaction Reports and Analysis Centre, (Queanbeyan, Australia, John Walker Consulting Services, September 1995); John Walker and Brigitte Unger, "Measuring global money laundering: the Walker gravity model”, Review of Law and Economics, vol 5 (2009); Brigitte Unger, The Scale and Impacts of Money Laundering (Cheltenham, Edward Elgar Publishing Company, 2007); Douglas Farah, "Money laundering and bulk cash smuggling: challenges for the Mérida Initiative", Working Paper Series on U.S.-Mexico Security Cooperation, Woodrow Wilson Center for International Scholars/Trans-Border Institute, University of San Diego, May 2010); United States, ONDCP, What America's Drug Users Spend on Illicit Drugs, 1988-2000, (Washington D.C., 2001); National Drug Intelligence Centre, National Drug Threat Assessment 2009, (Illicit Finance - Bulk Cash Smuggling) (Washington D.C., December 2008).
Another UNODC study developed a more detailed model for the cocaine trade: the share available for money laundering of both retail sales (proceeds) and gross profits was estimated at 62 per cent in 2009. ${ }^{61}$ But the proportion varied hugely along the supply chain. At the retail level, on average 44 per cent of gross profit from cocaine was available for money laundering; the proportion rose to 92 per cent at the wholesale level.

The UNODC study also suggested that the figure varied according to location. Overall, the proportion of gross profits available for laundering at the wholesale level ranged from 87 to 94 per cent, and

\section{Sectors where organized crime invests profits}

- Businesses that use cash

- Low-tech, labour-intensive and not export-oriented sectors

- Sectors with a high involvement of public administration and/or public subsidies

- Territorial-specific sectors, which can benefit and/or facilitate the control of the territory by criminal groups

- Sectors with weak or developing regulation, which may imply weaker monitoring or more infiltration opportunities (for example, renewable energy or gaming)

Source: Savona and Riccardi, eds., From Illegal

Markets to Legitimate Businesses: the Portfolio of

Organised Crime in Europe.

61 Estimating Illicit Financial Flows Resulting from Drug Trafficking and Other Transnational Organized Crime. 
TABLE 6 Net profits generated from the supply of heroin in seven western European countries (millions of euros)

\begin{tabular}{|c|c|c|c|c|c|c|c|c|}
\hline & \multicolumn{2}{|c|}{ Retail } & \multicolumn{2}{|c|}{ Middle market } & \multicolumn{2}{|c|}{ Wholesale } & \multicolumn{2}{|c|}{ Total } \\
\hline & $\min$ & $\max$ & $\min$ & $\max$ & $\min$ & $\max$ & $\min$ & $\max$ \\
\hline Revenues & 4.56 & 7.60 & 2.78 & 4.62 & 2.27 & 3.75 & 4.56 & 7.60 \\
\hline Gross profits & 1.77 & 2.97 & 0.51 & 0.87 & 0.65 & 1.09 & 2.93 & 4.94 \\
\hline $\begin{array}{l}\text { Net profits } \\
\text { (funds available for money laundering) }\end{array}$ & 0.08 & 1.28 & 0.44 & 0.80 & 0.64 & 1.08 & 1.16 & 3.16 \\
\hline $\begin{array}{l}\text { Net margin (proportion of revenues } \\
\text { available for money laundering) }\end{array}$ & $2 \%$ & $17 \%$ & $16 \%$ & $17 \%$ & $28 \%$ & $29 \%$ & $25 \%$ & $42 \%$ \\
\hline
\end{tabular}

Source: Savona and Riccardi, eds., From Illegal Markets to Legitimate Businesses: the Portfolio of Organised Crime in Europe.

\section{How drug money is} laundered

- Cash, including smuggling and stockpiling

- Hawala, an informal system of money transfer

- Purchase of real estate and related construction activities

- Investment into cash-generating activities such as restaurants, casinos, red-light entertainment, gas stations

- Purchase of luxury items such as villas yachts, jewels

- Investment in offshore centres

at the retail level from 32 to 50 per cent, between subregions. In North America, about half of cocainerelated gross profits at the retail level were available for laundering; in Western and Central Europe, the proportion was slightly lower ( 44 per cent). These figures suggested that 35 per cent of the income generated in cocaine retail sales in North America and 26 per cent in Western and Central Europe were available for laundering purposes. ${ }^{62}$ Similarly, a study of seven western European countries (Finland, France, Ireland, Italy, the Netherlands, Spain and United Kingdom) by Transcrime showed a broadly similar picture for heroin at the retail level. The study estimated that between 25 per cent and 42 per cent of overall heroin retail sales in 2010 were available for investment into the legal economy; another way of saying that those funds were available for money laundering. 63

62 Ibid.

63 Savona and Riccardi, eds., From Illegal Markets to Legitimate

\section{Cross-border laundering: illicit financiall flows}

Drug traffickers spend their profits in a variety of ways - from buying luxury items such as yachts and jewellery, to investing in real estate and using offshore financial centres. Some traffickers use laundering networks embedded into their overall organizational structure and directly employ accountants and lawyers; other groups outsource to "independent" networks that specialize in hiding the proceeds of crime. With the slow decline of hierarchical crime organizations and the emergence of loose hierarchical or networked structures, the trend is moving towards professional outsourcing.

While some drug money is laundered inside the country, some is hidden or reinvested across borders, constituting drug-related illicit financial flows. There is very limited information on the proportion and level of drug profits that are laundered outside the country. As with any commercial business, this will most likely depend on where the profits are to be enjoyed, and the margins that can be made on top of the money generated.

A model developed by UNODC for the 2009 cocaine market estimated that about 30 per cent of cocaine proceeds at the global level ${ }^{64}$ translated into illicit financial flows. ${ }^{65}$ Another study based on interviews with prisoners involved in the drug trade

\section{Businesses: the Portfolio of Organised Crime in Europe.}

64 The model arrived at a similar estimate for the proportion of gross profits from cocaine translating into illicit financial flows.

65 Estimating Illicit Financial Flows Resulting from Drug Trafficking and Other Transnational Organized Crime. 


\section{What are illicit financial flows?}

The term "illicit financial flows" is often used in different contexts where it may be associated with different mean-

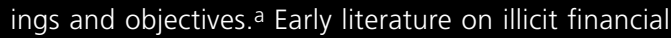
flows focused on capital flight from developing countries and disregarded whether the sources were licit or illicit. Critics say this methodology fails to capture processes such as bulk cash transfers, hawala payments or other transactions completed outside the official financial system. $b, c$

a World Bank, The World Bank Group's Response to Illicit Financial Flows: A Stocktaking (March 22, 2016).

b Volker Nitsch, "Trillion dollar estimate: illicit financial flows from developing countries", Darmstadt Discussions Papers in Economics, (December 2015). Available at: http://tuprints.ulb.tu-darmstadt.de/5437/1/ddpie_227. pdf.
Other approaches more explicitly link illicit financial flows to the outcome of illicit activities or the financing of organized crime and terrorism.

The most widely used definition nowadays considers illicit financial flows to be generated when crime-related proceeds (including money illegally earned, transferred or used) cross borders.

c Dev Kar and Joseph Spanjers, Financial Flows from Developing Countries: $2004-2013$ (Global Financial Integrity, December 2015). in Italy came to a similar conclusion, suggesting that roughly a third of the money spent by cocaine users was being laundered across borders. 66

But drug trafficking groups trying to launder money outside their countries will face costs, which will reduce the actual amounts that can be invested back into the licit economy. Large-scale operations looking to launder hundreds of millions of dollars could face fees of between 5 and 10 per cent, according to testimony from an undercover agent of the United States Drug Enforcement Administration who worked as a money launderer for a major cocaine smuggling operation in Colombia and Venezuela (Bolivarian Republic of). ${ }^{67}$

Examples from Afghanistan suggest that people using the informal hawala money remittance system had to pay 1 to 2 per cent of the total funds for a money transfer. ${ }^{68}$

66 Jonathan Caulkins and others, "Modelling the structure and operation of drug supply chains: the case of cocaine and heroin in Italy and Slovenia”, International Journal of Drug Policy (Elsevier, 2016), pp. 64-73.

67 Affidavit of Jaime X. Cepero, in Federal District Court of Massachusetts, 9 August 2013 (Melvin Soudijn and Peter Reuter, "Cash and carry: the high cost of currency smuggling in the drug trade", Crime Law and Social Change, vol. 66, No. 3 (Heidelberg, Springer, 2016), pp. 1-20)).

68 Ibid; Samuel Munzele Maimbo, "The money exchange dealers of Kabul, a study of the hawala system in Afghanistan", Working Paper No. 13 (World Bank, Washington D.C., 2003).

\section{Economic impact of drug money}

The flow of drug money from the hands of traffickers, through launderers, and finally into the licit economy, has all sorts of complex socioeconomic effects.

In the short term, an inflow of drug money back into the economy can boost investment and local GDP, generating employment and revenue. The long-term effects, however, tend to be negative, particularly when drug-related proceeds comprise a relatively larger portion of the total economy of a community or a country. In this scenario, drug money has the potential to inflate property prices, distort export figures, create unfair competition, reinforce skewed income and wealth distributions, ${ }^{69}$

World Drug Report 2012; Estimating Illicit Financial Flows Resulting from Drug Trafficking and Other Transnational Organized Crime; IMF, Anti-Money Laundering and Combating the Financing of Terrorism (AML/CFT) Report on the Review of the Effectiveness of the Program (Washington D.C., May 2011), Unger, The Scale and Impacts of Money Laundering; Naím, Moisés, Illicit: How Smugglers, Traffickers and Copycats are Hijacking the Global Economy (London, William Heinemann, 2006); Francisco E. Thoumi, Illegal Drugs, Economy, and Society in the Andes (Washington D.C., Woodrow Wilson Press, 2003); International Narcotics Control Board (INCB), Report of the International Narcotics Control Board for 2002 (New York, 2002); UNDCP, "The social impact of drug abuse", prepared for World Summit for Social Development, Copenhagen 6-12 March 1995; Lamond Tullis, "Illegal drugs in nine countries - socioeconomic and political consequences", report prepared for 
and increase corruption. In the process, legitimate businesses, without access to illicit funds, may be squeezed out of the market, and new legitimate investments may not take place. ${ }^{70}$ The rise of an illicit economy helps to weaken the rule of law and facilitates corruption, which in turn reinforces the vicious economic cycle.

When large amounts of illicit funds are available in an economy, criminally financed entities may take over some lending functions. In cases like those, government actions designed to stop economies from overheating, such as enforcing a restrictive monetary policy, may not work. This may prompt even more drastic monetary and fiscal measures. Money laundering can lead to volatility in exchange rates and interest rates owing to unanticipated inflows and outflows of capital, all of which tends to have a negative impact on overall economic growth. ${ }^{71}$

Studies suggest that the flow of laundered money, including drug proceeds, back into the domestic economy is associated with reductions in overall annual economic growth rates, ${ }^{72}$ particularly in smaller and less developed countries. One estimate, based on a study of 17 OECD countries, suggested that a $\$ 1$ billion increase in money laundering can reduce overall economic growth by between 0.03 and 0.06 percentage points. ${ }^{73}$

Several tax havens around the globe have been involved in money laundering activities - actively or unwittingly - and seem to have thrived economically, having witnessed an expansion in their financial service sectors. But international tolerance towards such behaviour is wearing thin, and calls have been made to develop strategies to prevent and

UNRISD and the United Nations University, published as Unintended Consequences; Illegal Drugs and Drug Policies in Nine Countries (Boulder, Colorado, Lynne Rienner, 1995); UNDCP, "Drugs and development", UNDCP Technical Series, No. 1 (Vienna, 1994); UNDCP, Economic and Social Consequences of Drug Abuse and Illicit Trafficking, UNDCP Technical Series, No. 6 (Vienna, 1998).

70 "Economic and Social Consequences of Drug Abuse and Illicit Trafficking.

71 Estimating Illicit Financial Flows Resulting from Drug Trafficking and Other Transnational Organized Crime.

72 Peter J. Quirk, "Money laundering: muddying the macroeconomy", Finance \& Development, vol. 34, No. 1 (IMF, March 1997), pp. 4-9

73 Unger, The Scale and Impacts of Money Laundering.

\section{How drug money affects the} economy

- Distorts resource allocation from high-yielding investments to investments that run a low risk of detectiona

- Distorts prices, including in the real estate sectorb

- Distorts exports and creates potential problems with investment and economic

- Creates unfair competition

- Crowds out licit activities and negatively affects direct foreign investmentc

- Deepens corruption

- Strengthens skewed income and wealth distributions ${ }^{\mathrm{d}}$

a Bartlett, "The negative effects of money laundering on economic development", p. 30; Estimating Illicit Financial Flows Resulting from Drug Trafficking and Other Transnational Organized Crime; INCB, Report of the International Narcotics Control Board for 2002, Sales No. E.03.XI.1, New York 2002.

b Estimating Illicit Financial Flows Resulting from Drug Trafficking and Other Transnational Organized Crime; Thoumi, Illegal Drugs, Economy, and Society in the Andes.

c Christine Ebrahimzadeh, "Dutch disease: wealth managed unwisely", IMF (28 March 2012). Available at www.imf.org/external/pubs/ft/fandd/basics/ dutch.htm.

d World Drug Report 2012; Estimating Illicit Financial Flows Resulting from Drug Trafficking and Other Transnational Organized Crime.

combat all illicit financial flows. ${ }^{74}$ Financial centres that do not adhere to international rules and regulations face legal sanctions ${ }^{75}$ and may eventually lose access to global financial markets, which could have potentially negative consequences for their own economic stability.

74 Doha Declaration on Integrating Crime Prevention and Criminal Justice into the Wider United Nations Agenda to Address Social and Economic Challenges and to Promote the Rule of Law at the National and International Levels, and Public Participation (General Assembly resolution 70/174, annex).

75 Brent. L. Bartlett, "The negative effects of money laundering on economic development", report for the Asian Development Bank (May 2002). 


\section{What the United Nations} Conventions say

"[I]llicit traffic generates large financial profits and wealth enabling transnational criminal organizations to penetrate, contaminate and corrupt the structures of government, legitimate commercial and financial business, and society at all its levels".

Preamble to the United Nations Convention against Illicit Traffic in Narcotic Drugs and Psychotropic Substances, 1988

"Corruption is an insidious plague that has a wide range of corrosive effects on societies. It undermines democracy and the rule of law, leads to violations of human rights, distorts markets, erodes the quality of life and allows organized crime, terrorism and other threats to human security to flourish".

Forward to the United Nations Convention against Corruption (UNCAC, 2003).

"Pursuant to article 4, paragraph 1, of the United Nations Convention against Corruption, which states that States parties shall carry out their obligations under the Convention in a manner consistent with the principles of sovereign equality and territorial integrity of States and non-intervention in the domestic affairs of other States, the Conference of the States Parties to the United Nations Convention against Corruption establishes the ... mechanism to review implementation of the Convention."

Terms of reference of the Mechanism for the Review of Implementation of the United Nations Convention against Corruption.

\section{THE DRUG PROBLEM AND CORRUPTION}

The drug problem and corruption have a mutually reinforcing relationship. Corruption facilitates the production and trafficking of illegal drugs and this, in turn, benefits corruption. ${ }^{76}$ The wealth and power of some drug trafficking organizations can exceed that of local governments, allowing them to buy protection from law enforcement agents, criminal justice institutions, politicians and the business sector. In doing so, they further reinforce corruption. The rule of law is both an immediate victim and, if it is already weak, an underlying factor that feeds this cycle.

\footnotetext{
76 Franciso Thoumi, Debates y Paradigmas de las Politicas de Drogas en el Mundo (Bogotá, 2015).
}

Despite this, there have been few attempts to get to grips with the relationship between the drug problem and corruption. Previous studies focused on specific events or geographical areas, but they have rarely taken a wider approach or tried to identify elements of the relationship across the whole illicit drug market. Better understanding of this relationship is vital not only to combat the illicit drug trade, but also to reduce corruption.

\section{Importance of assessing levels of corruption}

The Cosa Nostra and 'Ndrangheta have long benefited from high-level political connections in Italy. ${ }^{77}$ In a similar way, some Mexican drug cartels allegedly benefited from protection from local police and local politicians. ${ }^{78}$ In Guinea Bissau, international drug traffickers counted on the support of influential segments within the political and military apparatus for a number of years. ${ }^{79}$

This kind of activity is often called high-level corruption. It involves a small number of senior officials in the government, police, customs or the justice system being targeted in a business transaction with bribes in exchange for either passive or active support facilitating illegal activities. In several cases high-level corruption has posed a threat to the State. Organized criminal groups have attempted to influence the outcome of democratic processes; for example, by funding election campaigns in favour of specific candidates or political parties through "vote buying", intimidation or corrupting participants in the political process. Moreover, a corrupted judicial system and a lack of prison governance results in relative impunity.

By contrast, in the European Union much of the corruption reported appears to be on a low level, according to research by Europol. ${ }^{80}$ Political cor-

\footnotetext{
77 Letizia Paoli, "Italian organised crime: mafia associations and criminal enterprises", Global Crime, vol. 6, No. 1 (Taylor \& Francis Group, February 2004), pp. 19-31.

78 Richard Snyder and Angélica Durán-Martinez, "Drugs, violence, and state-sponsored protection rackets in Mexico and Colombia”, Colombia Internacional, No. 70 (Bogotá, Universidad de los Andes, July/Dec. 2009), pp. 61-91.

79 UNODC, Transnational Organized Crime in West Africa: A Threat Assessment (Vienna, February 2013); UNODC, Drug Trafficking as a Security Threat in West Africa (Vienna, November 2008).

80 EMCDDA and Europol, EU Drug Markets Report 2016,
} 
ruption at the level of elected national representatives or agency heads appears to be rare. However, Europol found that corruption of city councillors, mayors and other local level politicians was more common, especially in cities along the European Union's eastern land border. ${ }^{81}$ Overall, Europol concluded that organized crime groups involved in drug trafficking in Europe rely on corruption to facilitate their trafficking activities. ${ }^{82}$

The impact of high and low level corruption on local drug consumption and levels of violence is not always evident. The relationship with violence is neither straightforward, nor well understood. Violence is not always a direct outcome of drug trafficking, as demonstrated by the very different levels of violence registered worldwide in key transit or manufacturing countries. ${ }^{83}$ Whether more corruption means more or less violence is equally context specific. Depending on the underlying purpose of a bribe, the consequences may be different. Corruption is typically associated with weakened institutions; and weakened law enforcement bodies are by definition less capable of containing violent crime. In certain environments a corrupt equilibrium may temporarily create the impression of reduced violence; however, the negative effects of corruption in general become evident in the long run.

\section{Corruption along the drug supply chain}

For criminal organizations, the expected results of corrupting a public sector organization vary depending on the agency involved. For example, a criminal organization may seek to corrupt a customs officer to smooth the passage of drugs - by looking the other way when a shipment is passing or by informing traffickers of checks. Police may be targeted to obtain inside information on planned operations in order to protect ongoing illegal activities. Judges and prosecutors could be bribed or otherwise influenced to undermine police investigations, influence witnesses, reduce sentences or provide special prison treatment.

EMCDDA - Europol Joint publications (Luxembourg, Publications Office of the European Union, 2026), p. 38.

81 EU Drug Markets Report 2016.

82 SOCTA 2017.

83 World Drug Report 2016.
Different factors may affect the level of vulnerability of an institution. For example, if law enforcement officials and magistrates are paid barely enough to provide for their households or believe they are treated unfairly, they may be more vulnerable to bribes. Indeed, research suggests that an official's perception of how he or she is treated may have a greater effect on the organizational culture of integrity than the size of remuneration itself. ${ }^{84,} 85,86,87$, 88 Other important factors include the existence of effective internal control mechanisms, a strong organizational culture of ethics, or the presence of transparency and accountability mechanisms that help to promote public trust.

\section{Prosperity, corruption and drug markets}

The connection between corruption and economic development is often portrayed as asymmetrical: the lower the level of development, the greater the corruption. While there is evidence that this is true for bribery and other forms of low-level corruption, less is known about highlevel corruption in general.

Less advanced economies may not have the abundance of public resources available to build up strong institutions resilient to corruption, yet corruption itself will impede the process of generating, collecting and allocating such resources. Corruption and related forms of crime such as extortion discourage

84 "Fighting fraud in the Government", Austin Association of Certified Fraud Examiners. Available at: www.acfe.com/gf/.

85 Jeremy D. Foltz and Kweku A. Opoku-Agyemang, "Do higher salaries lower petty corruption? A policy experiment on West Africa’s highways". Available at http://cega.berkeley. edu/assets/miscellaneous_files/118_-_Opoku-Agyemang Ghana_Police_Corruption_paper_revised_v3.pdf.

86 Ting Gong and Alfred M. Wu, "Does increased civil service pay deter corruption? evidence from China”, MPRA Paper No. 41815 (Munich University Library, 2012). Available at https://mpra.ub.uni-muenchen.de/41815/1/MPRA_ paper_41815.pdf.

87 Deon Filmer and David L. Lindauer, "Does Indonesia have a "low pay" civil service?" Available at http://citeseerx.ist. psu.edu/viewdoc/download?doi=10.1.1.17.9760\&rep=rep1 \&type=pdf.

88 Mushtaq H. Khan, "Governance and anti-corruption reforms in developing countries: policies, evidence and ways forward", United Nations Conference on Trade and Development, G-24 Discussion Paper Series, No. 42 (November 2006). Available at http://unctad.org/en/docs/gdsmdpbg2420064_en.pdf. 


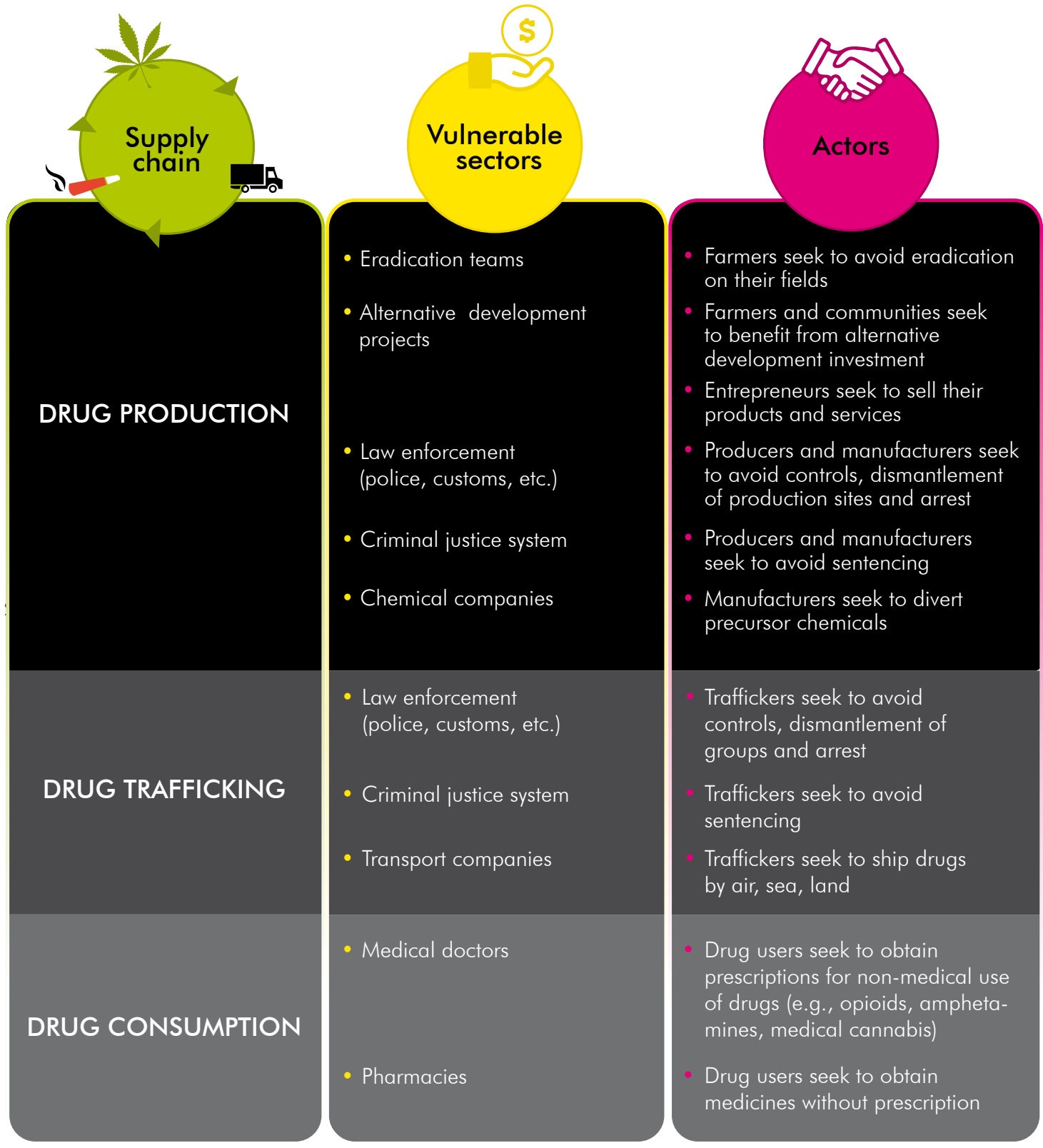

investment, entrepreneurship and business formation (which have prerequisites such as the rule of law and procedural transparency) and ultimately may be responsible for the hindrance of prosperity and economic development.

More broadly, World Bank research suggests that corruption entrenches poverty by discouraging foreign investment. ${ }^{89}$ This becomes even more pronounced if a country begins to develop a narcoeconomy; foreign businesses may decide to pull investment once they find out that the justice system

\footnotetext{
89 World Bank, "Combatting corruption", 11 May 2017. Available at http://www.worldbank.org/en/topic/governance/brief/anti-corruption.
} 
does not work any longer, correspondent banks close down as money laundering risks become too high, and potential investors steer clear because they fear their international image might suffer. All of this leads to lower levels of investment and growth, and a decline in some productive sectors of the economy. 90

In situations like that, local authorities may pay less attention to the origin of investment funds and accept criminal finance to fill the void. Moreover, corruption negatively affects business by raising transaction costs, which reduces investors' competitiveness and leads to a poorer financial performance overall. ${ }^{91}$

Studies confirm the relationship between development and bribery levels. As figure 4 shows, when the prevalence of bribery experienced by individuals in their dealings with public officials is analysed, ${ }^{92}$ it suggests that the police and the judiciary are the sectors most likely to be bribed in countries with low economic development.

According to research by the International Monetary Fund (IMF), corruption also increases the level of income inequality. ${ }^{93}$ This process particularly affects the poorer members of society, who can expect their income growth to be reduced and the likelihood of poverty to increase.

Higher levels of income inequality are also known to provoke drug trafficking and corruption. ${ }^{94}$ In fact, the drug industry may perpetuate and exacerbate income inequality, which may in turn cause

90 Report of the International Narcotics Control Board for 2002, pp 1-10.

91 Oman E. Hawthorne, "Do international corruption metrics matter? Assessing the impact of Transparency International's Corruption Perceptions Index", Dissertation, Old Dominion University (2015), pp. 77-78.

92 The prevalence of bribery is defined here as the percentage of the population that had contact with a public official and paid at least one bribe to such an official in the past 12 months.

93 Sanjeev Gupta, Hamid Davoodi and Rosa Alonso-Terme, "Does corruption affect income inequality and poverty?", Governance, Corruption, \& Economic Performance, George. T. Abed and Sanjeev Gupta, eds., Chapter 17 (IMF, 2002); Sanjeev Gupta, Hamid Davoodi and Rosa Alonso-Terme, "Does corruption affect income inequality and poverty?", IMF Working Paper, WP/98/76 (May 1998)

94 World Drug Report 2012 (United Nations publication, Sales No. E.12.XI.1).
FIG. 4 Prevalence of bribery, by type of public official and by level of income, 2013

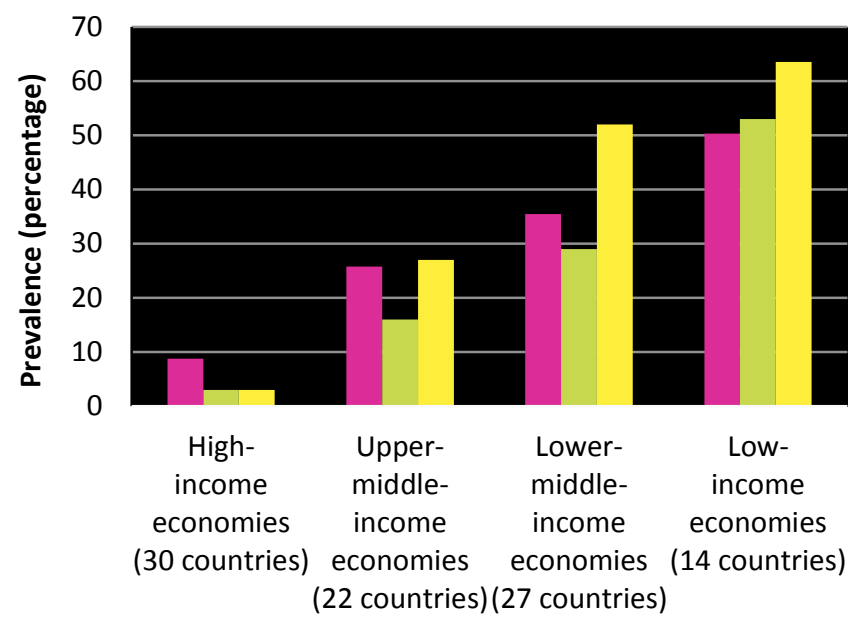

\section{Average of eight types $\quad$ Judiciary Police of public official}

Source: United Nations, Commission on Crime Prevention and Criminal Justice, World crime trends and emerging issues and responses in the field of crime prevention and criminal justice, 20 March 2016 E/CN/15/2016/10. Note: The average of eight types of public official includes officials from the following sectors: education, judiciary, medical and health, police, registry and permits, utilities, tax revenues and customs, and land services.

the expansion of drug production and trafficking. ${ }^{95}$ In unequal societies, members of marginalized groups may view corruption and involvement in criminal organizations as a viable way to improve their lives. ${ }^{96}$

Overall, corruption enables the growth of the illicit economy, which includes the illicit drug trade 97 and many other illegal activities, such as trafficking in cigarettes, persons, guns or counterfeit goods. A study for the European Union showed that levels of corruption and organized crime activities were highly correlated. ${ }^{98}$ This was particularly true for the illicit drug trade; the only criminal activity that benefited more from corruption was prostitution. 99

Report of the International Narcotics Control Board for 2002.

World Drug Report 2012.

SOCTA 2013; Michele Riccardi and Federica Sarno, "Corruption", Encyclopedia of Criminology and Criminal Justice, Gerben Bruinsma and David Weisbud, eds. (New York, Springer, 2013).

98 Philip Gounev and Tihomir Bezlov, Examining the Links Between Organised Crime and Corruption (Sofia, Center for the Study of Democracy, 2010).

99 Gouev and Bezlov, Examining the Links Between Organised 


\section{How to fight corruption}

The United Nations Convention on Corruption suggests a list of possible strategies to prevent and fight corruption, including

- Strengthening the effectiveness of law enforcement institutions, including through the introduction of further development of fair, merit-based human resource management practices, providing regular training and ensuring proper scrutiny of key personnel, such as background checks.

- Introducing codes of ethics and addressing conflicts of interest, inter alia through the introduction of assets and interest declarations systems.

- Considering rotation of officers in vulnerable positions where feasible to avoid creating permanent links with organized crime groups.

- Identifying the specific corruption risks in organizations and developing and implementing specific plans to address and mitigate them.

- Promoting the cooperation across different agencies to reduce the likelihood of success from bribing a limited number of officials and to increase the risk of detection.
- Ensuring that an array of enforcement measures exists to address corruption, including criminal justice and administrative or disciplinary procedures, as well as establishing effective systems for recovery of assets.

- Promoting effective international cooperation, including exchange of financial information.

- Establishing systems to encourage reporting of corruption by public officials and citizens as well as undertaking measures to protect reporting persons from retaliation or victimization. To this effect many countries make anonymous reporting of corruption possible.

- Introducing effective witness protection systems.

- Promoting transparency in funding of election campaigns, politicians and political parties.

- Raising the awareness of society as a whole, including students in schools and universities about negative consequences of corruption.

\section{Closing information gaps}

Much of the available information provides only a glimpse of the mechanisms of corruption used by traffickers. In addition to systematic reviews of drug and corruption prevention programmes to establish the most effective strategies, there is also a need for more detailed factual knowledge.

Many studies rely on "perceptions" of corruption. Important as this is to gauge public sentiment, other data are needed on the extent and nature of corruption across countries, and the ways in which it affects drug trafficking. The links between high-level and low-level corruption must be analysed to assess where each form is most likely to emerge, and how it will interact with different drug markets and political structures.

Finally, the relationship between corruption and violence needs further investigation. In some contexts it appears that corruption subdues violence; in other contexts drug trafficking organizations appear to be pushed towards greater levels of violence.

\section{DRUGS, TERRORISM AND INSURGENCY100}

From Latin America to the Middle East, funding for armed violence has in certain instances long been linked to the illicit drug trade.

By some estimates, around half of the income of the Taliban in Afghanistan comes from its involvement with narcotics (mostly opiates); 101 and FARC appears to have relied heavily on the cocaine trade for much of the past two decades - until recently — with estimates a few years ago suggesting that between one quarter and half of its total income was derived from such illicit drug activities. Armed groups in the Syrian Arab Republic are said to use amphetamine pills, and there are indications that terrorist organizations in West Africa might be involved in cocaine and cannabis smuggling.

The drug trade has been a significant source of income for some of those groups, for others it has

100 This section covers entities placed on the Consolidated United Nations Security Council Sanctions list and other insurgent and non-State armed groups.

101 Seventh report the Analytical Support and Sanctions Monitoring Team submitted pursuant to resolution 2255 (2015) concerning the Taliban and other associated individual and entities constituting a threat to the peace, stability and security of Afghanistan, S/2016/842, para. 15.
Crime and Corruption, quoted in EU Drug Markets Report 2016. 
been one of many revenue streams, while in some cases it may hardly have played a role at all.

\section{Terrorist, insurgent and non-State armed groups}

While there is no universally agreed definition of terrorism, the United Nations Security Council, regional organizations and Member State Governments have designated numerous armed groups as "terrorist" groups, and international treaties define terrorist offences. The Security Council has imposed sanctions on some 80 groups and more than 380 individuals linked to the Taliban, Al-Qaida and Islamic State in Iraq and the Levant (ISIL) on the grounds that they are involved in terrorist activities or support such activities. ${ }^{102}$ The Taliban, Al-Qaida, ISIL and its affiliate Boko Haram were responsible for 74 per cent of all deaths caused by terrorist, insurgent and non-State armed groups in 2015.103

The most comprehensive evidence linking the terrorist groups on which the Security Council has imposed sanctions in relation to the drug trade

\section{What the United Nations says}

"We, the States Members of the United Nations. [e]xpress deep concern about links between illicit drug production, trafficking and involvement of terrorist groups, criminals and transnational organized crime, and are resolved to strengthen our cooperation in response to those threats."

Political Declaration adopted by the special session of the General Assembly in June 1998

The General Assembly highlighted the need to "[r]espond to the serious challenges posed by the increasing links between drug trafficking, ... cybercrime and money-laundering, and in some cases terrorism, including money-laundering in connection with the financing of terrorism".

Outcome document of the special session of the General Assembly on the world drug problem held in 2016 (General Assembly resolution S-30/1, annex).

102 See the Consolidated United Nations Security Council Sanctions list.

103 Institute for Economics and Peace, Global Terrorism Index 2016. Available at http://visionofhumanity.org/?s=\%22Glob al+Terrorism+Index+2016\%22. relates to the Taliban, which has taxed entities involved in illicit drug production, manufacture and trafficking. It has also been directly involved in drug trafficking. ${ }^{104}$

Some evidence suggests that Al-Qaida in the Islamic Maghreb, which operates primarily in North and West Africa, has been involved in cannabis and cocaine trafficking, or at least in protecting traffickers, ${ }^{105}$ though the group's overall income from the drug sector appears to have been rather modest. ${ }^{106}$ Individual commanders of the Movement for Oneness and Jihad in West Africa, which broke away from Al-Qaida in the Islamic Maghreb, seem at present to be directly involved in drug trafficking. 107

In and around the Syrian Arab Republic, seizure data on "captagon" pills — typically amphetamine mixed with caffeine - suggest that a manufacturing hub exists in the area of operations of ISIL, Al-Qaida offshoot Jabhat Fateh al-Sham (formerly known as Al-Nusrah Front) 108,109 and other armed groups. ${ }^{110}$ ISIL and other non-State armed groups have been linked in media reports to the production of "captagon", but no conclusive evidence has

104 Security Council, "Letter dated 18 August 2015 from the Chair of the Security Council Committee established pursuant to resolution 1988 (2011) addressed to the President of the Security Council" (26 August 2015); UNODC, The Opium Economy in Afghanistan, An International Problem (New York, 2003); UNODC, Addiction, Crime and Insurgency - The Transnational Threat of Afghan Opium (Vienna 2009); UNODC, The Global Afghan Opium Trade - A Threat Assessment (Vienna, July 2011).

105 Daurius Figueria, Cocaine Trafficking in the Caribbean and West Africa in the Era of the Mexican Cartels (iUniverse, Bloomington, Indiana, November 2012); Stephen A. Harmon, Terror and Insurgency in the Sahara-Sahel Region: Corruption, Contraband, Jihad and the Mali War of 20122013 (Routledge, 2014).

106 Marc Mémier, “Aqmi et Al-Mourabitoun: le djihad sahélien réunifié ?” Études de l'Ifri (January 2017), pp. 31-34.

107 Ibid.

108 Report of the Secretary-General on the threat of terrorists benefiting from transnational organized crime (S/2015/366).

109 The Al-Nusrah Front was rebranded in 2016 as Jabhat Fateh al-Sham and announced breaking ties with Al-Qaida (ABC News, "Syrian branch of Al Qaeda rebrands in effort to escape foreign air strikes", 29 July 2016. Available at: http://www.abc.net.au/news/2016-07-29/al-nusra-rebrandsin-effort-to-escape-foreign-air-strikes/7671390).

110 World Drug Report 2016. 
emerged so far. ISIL fighters ${ }^{111}$ as well as those of other groups involved in the civil war in the Syrian Arab Republic have also been reported to consume "captagon". 112, 113

Based mainly in Nigeria and neighbouring countries, Boko Haram has reportedly helped drug traffickers to smuggle heroin and cocaine across the subregion. ${ }^{114}$ Further links between the group and the drug trade were revealed during a court case in Chad. In its judgment of 28 August 2015 in the trial of 10 alleged Boko Haram members, the N'djamena court of appeals heard that considerable quantities of psychotropic substances had been recovered during the search of the home of one of the Boko Haram defendants. The court concluded that Boko Haram members were regularly involved in the trafficking in and consumption of those substances. ${ }^{115}$

While drug markets and terrorist groups may in some cases go hand in hand, there have been examples of terrorist groups whose influence led to reductions in drug cultivation, at least temporarily. The Taliban's opium poppy ban in 2001 led to a drastic reduction in cultivation in Afghanistan, though they did not maintain this policy and in subsequent years actively participated again in the flourishing drug sector.

111 Max Kravitz and Will Nichol, "A bitter pill to swallow: connections between captagon, Syria and The Gulf", Journal of International Affairs, vol. 69, No. 2 (18 May 2016).

112 Lukasz Kamieński, Shooting up: A Short History of Drugs and War (New York, Oxford University Press, 2016); Zeinab Abul-Magd and Elke Grawert, Businessmen in Arms: How the Military and other Armed Groups Profit in the MENA Region (New York, Rowman \& Littlefield, 2016); Vijay Prashad, The Death of the Nation and the Future of the Arab Revolution (University of California Press, Oakland, California, 2016); Solomon Hussein, Islamic State and the Coming Global Confrontation, University of the Free State (Palgrave Macmillan, Bloemfontain, 2016); Robert J. Bunker, Blood Sacrifices: Violent Non-State Actors and Dark Magico-Religious Activities, A Terrorism Research Center Book (Bloomington, 2016).

113 Kravitz and Nichol, "A bitter pill to swallow: connections between captagon, Syria and the Gulf".

114 South Front, "Video: arms and drug trafficking in Africa. The role of Boko Haram", Centre for Research on Globalization (14 March 2016). Available at www.globalresearch. $\mathrm{ca} /$ video-arms-and-drug-trafficking-in-africa-the-role-ofboko-haram/5514293.

115 Judgment of 28 August 2015 by the N'djamena (Chad) court of appeals.
More recently, opium cultivation declined rapidly in some districts of the Afghan province of Nangarhar in 2016 after ISIL banned the practice in areas under its control. Neighbouring districts, by contrast, saw huge increases in cultivation in the same period. ${ }^{116}$ However, ISIL does not appear to have a consistent anti-drug stance. The Security Council Committee reported that ISIL fought against the Taliban in 2015 for control of drug trafficking profits in Nangarhar. ${ }^{117}$ ISIL now controls just a few districts in Nangarhar and no longer seems to systematically interfere with drug production, although they still may do so in individual cases.

Looking beyond entities on which the Security Council has imposed sanctions, individual United Nations Member States and non-governmental organizations identify several additional organizations as either terrorists, insurgents or non-State armed groups.

The most substantial evidence linking such groups to drug trafficking comes from Colombia, where they began to play a direct role in the drug trade in the 1980s and gained importance in the 1990s. They provided security for coca crops, and taxed the introduction of precursor chemicals and the use of landing strips. ${ }^{118}$ FARC in particular played a prominent role in taxing different aspects of the production chain and in selling coca paste, and later became involved in the cocaine trade to neighbouring countries. ${ }^{119,120}$

In neighbouring Peru, the Shining Path (Sendero Luminoso) used the profits from cocaine processing

$116 \mathrm{MCN}$ and UNODC, Afghan Opium Survey 2016 - Cultivation and Production (Vienna, 2016).

117 United Nations Security Council, "Letter dated 18 August 2015 from the Chair of the Security Council Committee established pursuant to resolution 1988 (2011) addressed to the President of the Security Council”, 26 August 2015.

118 Arlene Beth Tickner, Diego García and Catalina Arreaza, "Actores violentos no estatales y narcotráfico en Colombia", Politica Antidrogas en Colombia: Exitos, fracasos y extravios (Bogotá, 2011).

119 Richard Snyder and Angelica Duran-Martinez, "Does illegality breed violence? Drug trafficking and state-sponsored protection rackets." Crime, Law and Social Change, vol. 52, No. 3 (Springer, 2009), pp. 253-273.

120 M. Romero, "Paramilitares y autodefensas 1982-2003", Instituto de Estudios Políticos y Relaciones Internacionales Universidad Nacional de Colombia (Bogotá, 2003). 
plants to fund its activities over four decades. ${ }^{121}$ The group was particularly active in the 1990s.

Insurgent groups and rebel armies operating in eastern Myanmar, notably in Shan state, have reportedly been involved in the heroin trade for the past six decades $^{122}$ and in methamphetamine manufacturing and trafficking for the past two decades. ${ }^{123}$

Elsewhere in the world, the evidence supporting links between terrorist, insurgent and non-State armed groups and the illicit drug trade is less rigorous.

\section{Funding of terrorist, insurgent and non-State armed groups}

Data on the funding of terrorist, insurgent and nonState armed groups is incomplete, with estimates varying widely; all aggregations must be treated with caution. However, such figures can give some likely orders of magnitude.

UNODC estimated that terrorist and insurgent groups raised about $\$ 150$ million in 2016 from the Afghan opiate trade in taxes levied on the cultivation of opium poppy and trafficking of opiates. ${ }^{124}$ Their overall drug-related income, however, may be higher. The Consolidated Security Council Sanctions List features a number of Taliban leaders who are accused not only of taxing the drug business, but also of direct involvement in trafficking. ${ }^{125}$ The Security

121 Mirella von Dun, Cocaleros - Violence, Drugs and Social Mobilization in the Post-Conflict Upper Huallaga Valley, Peru (Amsterdam, 2009); Francisco E. Thoumi, Debates y Paradigmas de las Politicas de Drogas en el Mundo y los Desafiós para Colombia (Bogotá, Academia Colombiana de Ciencias, 2015), pp. 448-449; Patricik L. Clawson and Rensselaer W. Lee III, The Andean Cocaine Industry (Palgrave Macmillan US, 1998) pp. 180-183.

122 Letizia Paoli, Victoria A. Greenfield and Peter Reuter, The World Heroin Market: Can Supply Be Cut? (New York, Oxford University Press, 2009); Howard Abadinsky, Organized Crime 11 ed. (Boston, Cengage Learning, 2016).

123 Pierre-Arnau Chouvy and Joël Meissonier, Yaa Baa: Production, Traffic and Consumption of Methamphetamine in Mainland Southeast Asia (Singapore University Press, 2004); Abadinsky, Organized Crime.

124 Sustainable Development in an Opium Production Environment-Afghanistan Opium Survey Report 2016.

125 The list, in addition, contains companies with close links to the Taliban and the drug business, including trading companies, money exchanges and hawala (money transfer) companies that support Taliban military operations and the drug trade in Afghanistan.
Council Committee established pursuant to resolution 1988 (2011) estimated the overall annual income of the Taliban from all sources at around $\$ 400$ million, ${ }^{126}$ half of which was likely to have been derived from the illicit narcotics economy. ${ }^{127}$

In Colombia, FARC seems to have been heavily reliant on coca/cocaine-related income, particularly at the turn of the new millennium. Despite a drop in revenue as the Colombian coca/cocaine sector started shrinking, drug-related income appears to have remained an important source of income in subsequent years as well. As an outcome of the peace process and the Peace Agreement signed in 2016, there is now agreement that FARC is to halt its involvement in the drug business as it turns into a legal political force.

Estimates of the income generated by the illicit drug trade need to be considered from the perspective of the overall income of terrorist, insurgent and other non-State armed groups, for which there is very little authoritative information. For example, Forbes International attempted to value the world's 10 richest terrorist and other groups, with an estimated total combined income of $\$ 4.9$ billion in 2014 . The reported income distribution, however, appears to have been highly skewed, ranging from $\$ 25$ million to $\$ 2$ billion among the 10 richest organisations. ${ }^{128}$

More than half of the income was attributed to groups officially recognized by the United Nations as terrorist organizations (ISIL, Taliban, Al-Qaida, Al-Shabaab and Boko Haram). ${ }^{129}$ ISIL was estimated to be the richest terrorist group in 2014, with a turnover of roughly $\$ 2$ billion. However, ISIL suffered territorial losses and therefore obtained lower tax income and revenue from oil and less potential for looting and confiscations. As a result,

126 First report of the Analytical Support and Sanctions Implementation Monitoring Team submitted pursuant to resolution 1988 (2011) concerning the Taliban and associated individuals and entities (S/2012/683), para. 34.

127 S/2016/842, para. 15 .

128 Forbes International, "The world's 10 richest terrorist organizations” (12 December 2014). Available at https:// www.forbes.com.

129 Taking estimates of the "richest" terrorist/insurgency groups as a basis (derived from interviews with representatives of the intelligence community, security experts, counter-terror specialists as well as reports and analyses from international non-governmental organizations, academic and government organizations and think tanks). 
the group's income had reportedly declined by more than half by 2016,130 although it is likely that their expenses also declined sharply as they were no longer in control of as many cities and villages as before.

\section{Drugs and terror attacks}

Some 170,000 people lost their lives in terror attacks between 2000 and 2015, including 30,000 in 2015 alone, according to the Global Terrorism Database, ${ }^{131}$ the largest systematic collection of open-source information on terrorism acts worldwide. The database, which has information on 163 countries going back to 1970 , uses the umbrella term "terrorism" to cover attacks by terrorists, non-State armed groups, rebels and insurgents.

In some cases, there is a positive correlation between terror attacks, as defined by the Global Terrorism Database, and the world's most intensive areas of drug manufacturing and trafficking as reported in 2015. Some of those areas see a significant number of terrorist incidents. However, a correlation does not necessarily point to a causal link. Some areas where the drug trade is intensive are not significantly affected by terrorism, and vice versa.

\section{Opium poppy cultivation and insurgency in Afghanistan}

Afghanistan, accounting for close to 13 per cent of all terrorism-related deaths worldwide between 2000 and 2015, gives a great insight into the potential link between drug production and terrorism. ${ }^{132}$

The Taliban was responsible for 73 per cent of all terrorism-related deaths in Afghanistan during the period 2000-2015, and 84 per cent of such deaths in 2015. This was followed by ISIL, which accounted for 4 per cent of the total in 2015.133

High levels of insecurity in Afghanistan have been related to a range of events: conflict, disputes and terrorist activities. They have also been associated

\footnotetext{
130 Stefan Heissner and others, "Caliphate in decline: an estimate of Islamic State's financial fortunes” (London, The International Centre for the Study of Radicalisation and Political Violence, 2017). Available at http://icsr.info.

131 National Consortium for the Study of Terrorism and Responses to Terrorism (START), Global Terrorism Database (June 2016). Available at www.start.umd.edu/gtd.

132 Ibid.

133 Ibid.
}

with opium poppy cultivation; however, it is only since 2010 that high and increasing levels of opium cultivation have shown a closer correlation with rising terrorist attacks. The reasons for this are complex, but armed groups have found it increasingly difficult to access "traditional" funding sources, which may have resulted in a stronger reliance on "alternative" financing such as drug trafficking.

The post-2010 rise in violence is also linked to a number of other factors, including the withdrawal of North Atlantic Treaty Organization (NATO) forces and subsequent disbanding of provincial reconstruction teams, the emergence of destabilizing groups opposing the peace process, and the expansion of the illicit economy into new areas such as the illegal exploitation of natural resources, which has led to the emergence of new insurgent groups.

More broadly, the areas under opium poppy cultivation in Afghanistan are, to varying degrees, controlled by diverse terrorist, insurgent and other armed groups, including the Taliban. Between 26 per cent and 85 per cent of the area under opium poppy cultivation is estimated to be under varying degrees of Taliban influence.

\section{FIG. 5 Persons killed in terrorist attacks and area under opium poppy cultivation in Afghanistan, 2000-2016}

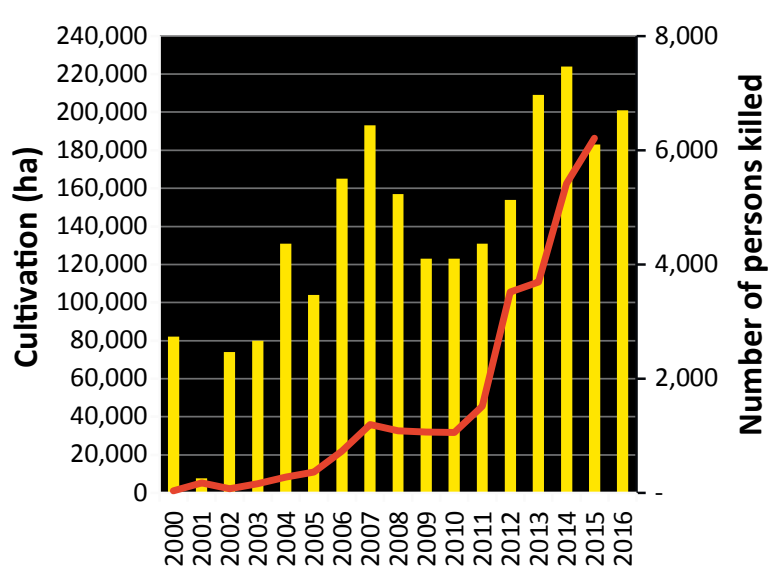

Area under opium poppy cultivation Persons killed in terrorist attacks

Source: MCN and UNODC, Afghanistan Opium Survey 2016 - Cultivation and Production (Vienna, 2016), and previous years; Global Terrorism Database. 
MAP 1 Area under control of insurgent groups and area under opium poppy cultivation in Afghanistan, 2016

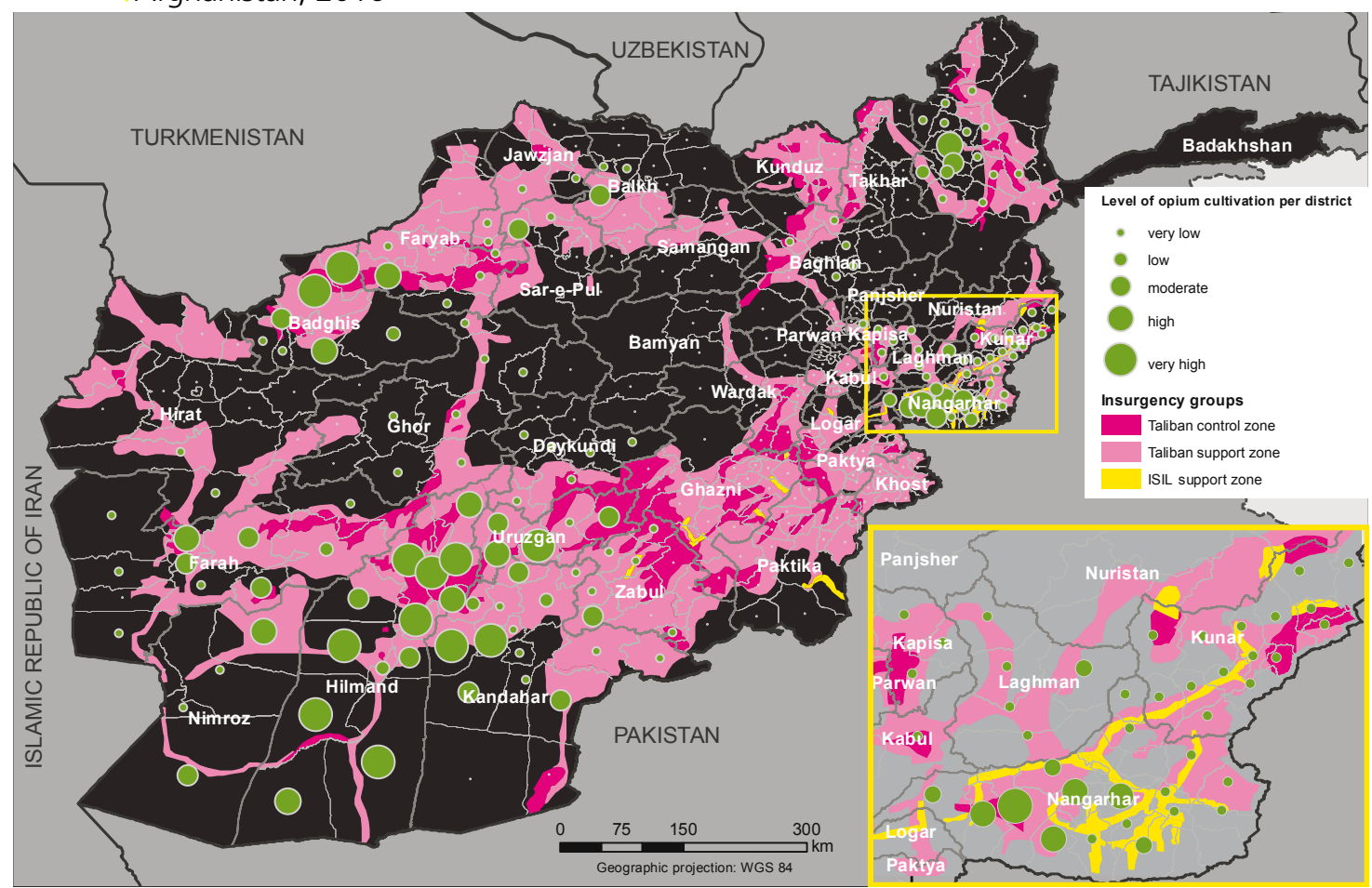

Source: MCN and UNODC, Afghanistan Opium Survey 2016 - Cultivation and Production (Vienna, 2016). Insurgency groups taken from the Institute for the Study of War, November 2016.

Note: the boundaries and names shown and the designations used on this map do not imply official endorsment or acceptance by the United Nations. Dashed lines represents undetermined boudaries. Dotted line represents approximately the Line of Control in Jammu and Kashmir agreed upon by India and Pakistan. The final status of Jammu and Kashmir has not yet been agreed upon by the parties. The insurgency groups are mapped with different classes of confidence, which have been merged for the purpose of this map. Geographic projection: WGS 84 .

TABLE 7 Distribution of opium poppy cultivation areas according to variations in level of control by insurgent groups, Afghanistan, 2016

\begin{tabular}{|c|c|c|c|c|c|c|c|c|}
\hline & $\begin{array}{l}\text { Opium } \\
\text { poppy } \\
\text { cultivation } \\
2016\end{array}$ & $\begin{array}{l}\text { Opium } \\
\text { poppy in } \\
\text { Taliban } \\
\text { control } \\
\text { zone }\end{array}$ & $\begin{array}{l}\text { Opium poppy } \\
\text { in High- } \\
\text { confidence } \\
\text { Taliban } \\
\text { support zone }\end{array}$ & $\begin{array}{l}\text { Opium poppy } \\
\text { in Low- } \\
\text { confidence } \\
\text { Taliban } \\
\text { support zone }\end{array}$ & $\begin{array}{l}\text { Opium } \\
\text { poppy } \\
\text { in three } \\
\text { Taliban } \\
\text { support } \\
\text { zones }\end{array}$ & $\begin{array}{l}\text { Opium } \\
\text { poppy } \\
\text { in High- } \\
\text { confidence } \\
\text { ISIL support } \\
\text { zone }\end{array}$ & $\begin{array}{l}\text { Opium } \\
\text { poppy } \\
\text { in Low- } \\
\text { confidence } \\
\text { ISIS support } \\
\text { zone }\end{array}$ & $\begin{array}{l}\text { Opium } \\
\text { poppy } \\
\text { in other } \\
\text { areas }\end{array}$ \\
\hline Area (ha) & 201,294 & 52,642 & 116,135 & 2,490 & 171,267 & 2,229 & 623 & 43,400 \\
\hline Proportion & $100 \%$ & $26 \%$ & $58 \%$ & $1 \%$ & $85 \%$ & $1.1 \%$ & $0.3 \%$ & $13 \%$ \\
\hline
\end{tabular}

Source: MCN and UNODC, Afghanistan Opium Survey 2016 - Cultivation and Production (Vienna, 2016); Government of Afghanistan. Insurgency groups taken from the Institute for the Study of War, November 2016.

A socioeconomic survey conducted in Afghanistan in 2016 revealed that villages with opium poppy cultivation are more likely to be under the influence of anti-government groups (61 per cent) than villages without opium poppy cultivation. Moreover, it was found that the increased influence of insurgency groups and a deterioration in the security situation in the north of the country coincided with an increase in opium poppy cultivation. Clearly, a lack of government control is conducive to the expansion and persistence of opium poppy cultivation. ${ }^{134}$

\footnotetext{
134 Sustainable Development in an Opium Production Environment - Afghanistan Opium Survey Report 2016.
} 
FIG. 6 Government control of villages, by poppy-cultivation status, Afghanistan, 2016

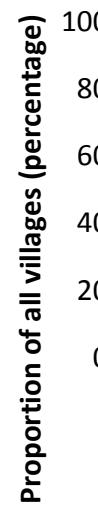
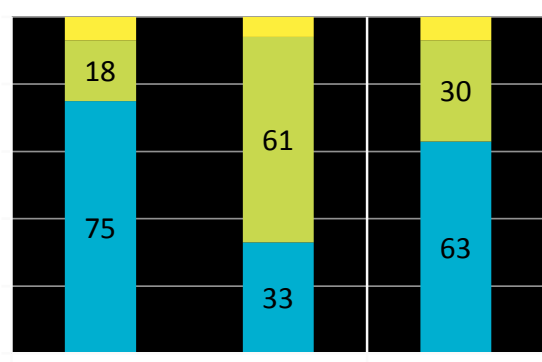

Without With poppy National poppy cultivation cultivation

\section{Others}

Anti-government

- Central/regional/local government

Source: UNODC and MCN, Sustainable Development in an Opium Production Environment - Afghanistan Opium Survey Report 2016 (Vienna, 2017).

\section{Drug cultivation and terrorist, insurgent and non-State armed groups in Peru, Colombia and Myanmar}

Examples in Peru, Colombia and Myanmar show the complex relationship between drug cultivation and the activities of terrorist, insurgent and nonState armed groups. While a causal relationship cannot be established, reductions in drug cultivation can go in parallel with lower levels of activity by such groups; and lower levels of insurgent activities can help to strengthen the application of the rule of law by the authorities and thus contribute to a reduction in illicit drug cultivation.

In Peru, the area under coca cultivation shrank by nearly 70 per cent from its peak in 1992 to 2015.135 During the same period, the number of people killed by terrorist, insurgent and non-State armed groups fell from 818 in 1992 to six in 2015; most of those

FIG. 7 Attacks by terrorist, insurgent and non-State armed groups and area under coca cultivation, Peru, 1978-2016

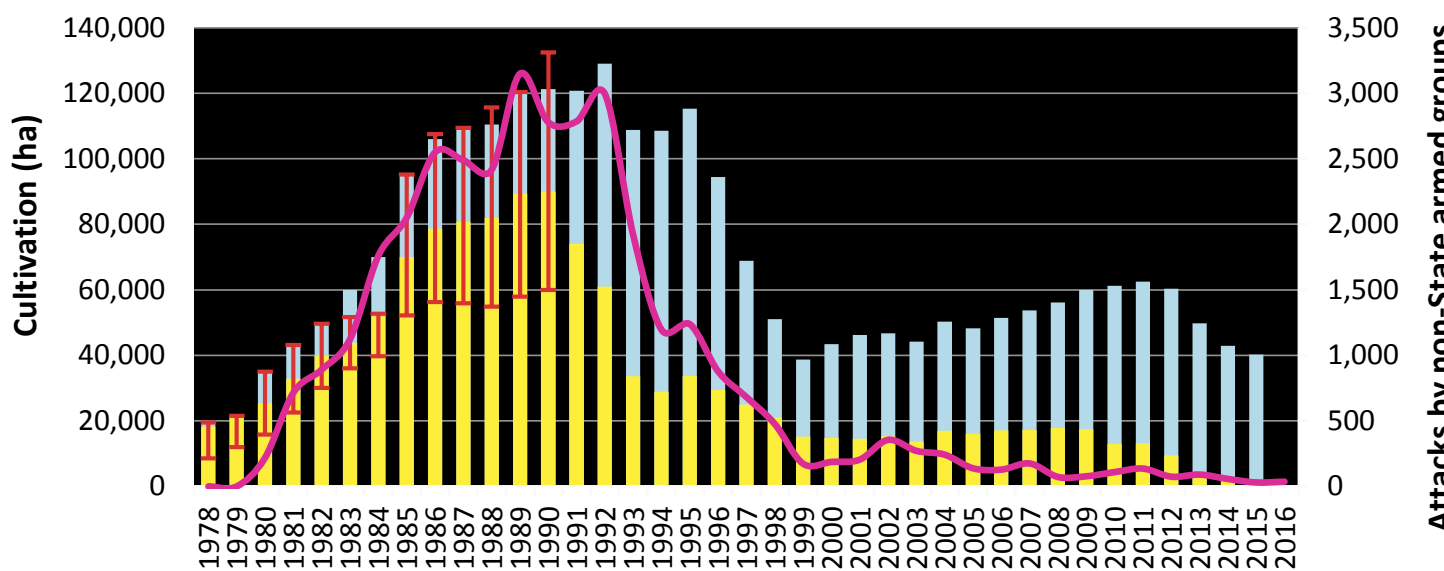

Sources: UNODC and Comisión Nacional para el Desarrollo y Vida sin Drogas (DEVIDA), Perú Monitorea de Cultivos de Coca 2015 (July 2016 and previous years); DEVIDA, Información sobre Drogas Estadística en el Perú, Lima (July 2006); Policía Nacional del Perú, Anuario Estadístico 2015 (2015 and previous years); Policía Nacional del Perú, Direccíon Contra el Terrorismo, Anuario Estadístico 2009; Hernán Manrique López, "Las bases históricas del milagro de San Martin: control territorial y estrategias estatales contra el narcotráfico y subversión (198-1995)", Politai: Revista de Ciencia Política, vol. 6, No. 11 (2015), pp. 33-51; Juan Briceño and Javier Martínez, "El ciclo operativo del tráfico ilícito de la coca y sus derivados: implicancias en la liquidez del sistema financiero", F. León, y R. Castro de Mata, eds., Pasta básica de cocaína (Lima, 1989), pp. 263-264; Ibán De Rementería, "Evolution of coca leaf production in Peru and its macroeconomic role between 1978 y 1990", Peru Report, April 1991. 
fatalities were the result of operations by the Shining Path, which was behind 772 deaths in 1992, but just three in 2015.136 Most operations by the Shining Path took place in, or close to, the Alto Huallaga region, which used to be the main coca cultivation area in Peru. This is also illustrated by the number of attacks and casualties suffered by the personnel of Proyecto Especial de Control de Cultivos de Coca (CORAH). Between 2005 and 2012 there were around 30 attacks, with 133 injuries and 11 deaths of CORAH personnel. The number of attacks by terrorist, insurgent and non-State armed groups over the past three decades shows a positive correlation with the area under coca cultivation in the Alto Huallaga region, with declines in coca cultivation since the early 1990s going hand in hand with declines in attacks.

Similarly, in Colombia the area under coca cultivation shrank by 70 per cent between 2000 and 2013 during a decline in the number of operations by FARC. 137 The number of victims of violence by non-State armed groups also showed a marked decline over the same period. ${ }^{138}$ The number of people killed by non-State armed groups fell from 426 in 2000 to 137 in 2013; among them, the number killed by FARC declined by almost 60 per cent, from 256 in 2000 to 106 in $2013 .{ }^{139}$ However, the apparent connection between coca cultivation and violence has become less straightforward in recent years. Cultivation doubled between 2013 and 2015 even as FARC-related killings declined further, by more than half.

In Myanmar, there is a weaker correlation between the activities of various non-State armed groups and insurgents and the area under opium poppy cultivation. ${ }^{140}$ The number of people killed in terror attacks fell from 86 in 1996 to zero in 2006. They rose again to 58 by 2015,141 when the area under opium poppy cultivation had tripled.

\footnotetext{
136 Global Terrorism Database.

137 World Drug Report 2016 and previous years.

138 Unidad para la Atención y Preparación Integral a las Víctimas, Red Nacíonal de Información, "Registro único de víctimas" (1 April 2017). Available at http://rni.unidadvictimas.gov.co/RUV.

139 Global Terrorism Database.

140 World Drug Report 2016 and previous years.

141 Global Terrorism Database.
}

FIG. 8 Registered victims* of non-State armed violence and area under coca cultivation, Colombia, 2000-2016

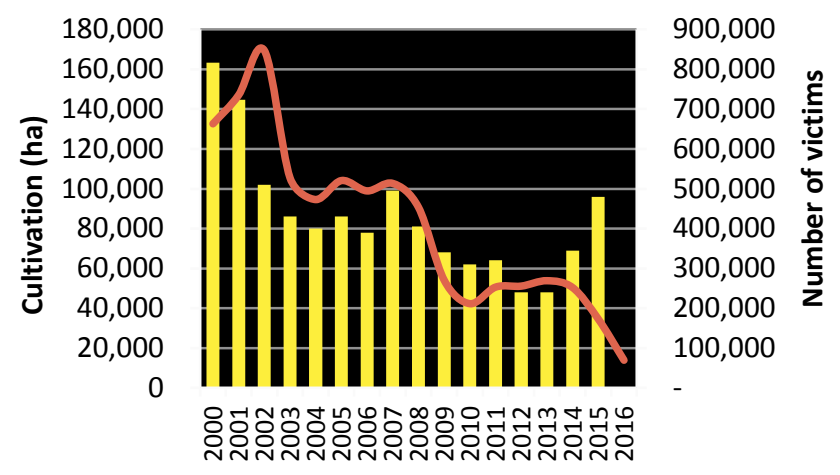

Area under coca cultivation Victims of violence by non-State armed groups

* Victims of terrorist attacks, related homicides, mines, kidnapping, forced displacements, forced disappearance, torture, etc.

Sources: UNODC and Gobierno de Colombia, Colombia Monitoreo de territorios afectados por cultivos ilícitos 2015 (July 2016 and previous years); Unidad para la Atención y Peparación Integral a las Víctimas, Red Nacíonal de Información, "Registro único de víctimas". Available at http://rni.unidadvictimas.gov.co/RUV.

FIG. 9 Number of persons killed by terror attacks and area under opium poppy cultivation, Myanmar, 1996-2015

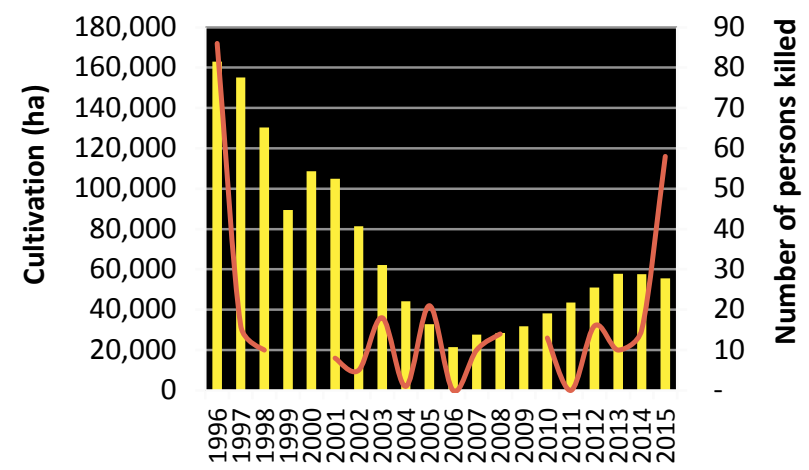

\section{Area under opium poppy cultivation} Persons killed in terror attacks

Sources: UNODC, Southeast Asia Opium Survey 2015 (Vienna, 2016), and previous years; Global Terrorism Database.

\section{Terror tactics and drug money}

Evidence on the links between drugs, terrorism and insurgency is patchy, focuses on a small number of groups, or builds on sources with an interest in emphasizing or diminishing those links. Most information on terrorism is collected by intelligence agencies and 
is classified. Open-source information largely comes from media reports and studies by non-governmental organizations and think tanks. Governments rarely release detailed information to the public.

Nevertheless, it is possible to draw some tentative conclusions. In general, income linked to the drug sector is only one of several revenue streams for terrorist groups. If one revenue stream dries up, another can be tapped, such as extortion, kidnapping for ransom, bank robberies, sale of natural resources or sale of cultural artefacts. ${ }^{142}$ As a result, reducing drug production and drug trafficking may not be sufficient to effectively squeeze the financial resources of terrorist and other non-State armed groups and insurgents. At the same time, there is evidence that drug production and the activities of some of these groups may go hand in hand in some areas.

Their level of dependence on the drug trade whether taxing farmers, protecting routes and trade, or direct involvement in production and trafficking - will be determined by their size, structure, ideology, location and existence of alternative financial sources. The prominence of drugs in financing will thus vary strongly from one group to another.

Insurgents aiming to control large amounts of territory are likely to need large financial resources, and involvement in organized crime activities, such as the drug business, may at least partly cover those funding needs. Yet much will depend on their strategy. A pointed attack focused on maximising media exposure and creating fear and intimidation does not necessarily need large or sustained funding. In fact, channelling smaller amounts of money through operations of that nature can reduce the risk of detection. Besides, there will always be a large number of "soft targets" for such an attack, which can easily be exploited by terrorists with or without drug money. 


\section{GLOSSARY}

amphetamine-type stimulants - a group of substances composed of synthetic stimulants that were placed under international control in the Convention on Psychotropic Substances of 1971 and are from the group of substances called amphetamines, which includes amphetamine, methamphetamine, methcathinone and the "ecstasy"-group substances (3,4-methylenedioxymethamphetamine (MDMA) and its analogues).

amphetamines - a group of amphetamine-type stimulants that includes amphetamine and methamphetamine.

coca paste (or coca base) - an extract of the leaves of the coca bush. Purification of coca paste yields cocaine (base and hydrochloride).

"crack" cocaine - cocaine base obtained from cocaine hydrochloride through conversion processes to make it suitable for smoking.

cocaine salt — cocaine hydrochloride. new psychoactive substances - substances of abuse, either in a pure form or a preparation, that are not controlled under the Single Convention on Narcotic Drugs of 1961 or the 1971 Convention, but that may pose a public health threat. In this context, the term "new" does not necessarily refer to new inventions but to substances that have recently become available.

opiates - a subset of opioids comprising the various products derived from the opium poppy plant, including opium, morphine and heroin.

opioids - a generic term applied to alkaloids from opium poppy (opiates), their synthetic analogues (mainly prescription or pharmaceutical opioids) and compounds synthesized in the body. 



\section{REGIONAL GROUPINGS}

The World Drug Report uses a number of regional and subregional designations. These are not official designations, and are defined as follows:

- East Africa: Burundi, Comoros, Djibouti, Eritrea, Ethiopia, Kenya, Madagascar, Mauritius, Rwanda, Seychelles, Somalia, Uganda and United Republic of Tanzania

- North Africa: Algeria, Egypt, Libya, Morocco, South Sudan, Sudan and Tunisia

- Southern Africa: Angola, Botswana, Lesotho, Malawi, Mozambique, Namibia, South Africa, Swaziland, Zambia and Zimbabwe

- West and Central Africa: Benin, Burkina Faso, Cameroon, Cabo Verde, Central African Republic, Chad, Congo, Côte d'Ivoire, Democratic Republic of the Congo, Equatorial Guinea, Gabon, Gambia, Ghana, Guinea, Guinea-Bissau, Liberia, Mali, Mauritania, Niger, Nigeria, Sao Tome and Principe, Senegal, Sierra Leone and Togo

- Caribbean: Antigua and Barbuda, Bahamas, Barbados, Bermuda, Cuba, Dominica, Dominican Republic, Grenada, Haiti, Jamaica, Saint Kitts and Nevis, Saint Lucia, Saint Vincent and the Grenadines and Trinidad and Tobago

- Central America: Belize, Costa Rica, El Salvador, Guatemala, Honduras, Nicaragua and Panama

- North America: Canada, Mexico and United States of America

- South America: Argentina, Bolivia (Plurinational State of), Brazil, Chile, Colombia, Ecuador, Guyana, Paraguay, Peru, Suriname, Uruguay and Venezuela (Bolivarian Republic of)
- Central Asia and Transcaucasia: Armenia, Azerbaijan, Georgia, Kazakhstan, Kyrgyzstan, Tajikistan, Turkmenistan and Uzbekistan

- East and South-East Asia: Brunei Darussalam, Cambodia, China, Democratic People's Republic of Korea, Indonesia, Japan, Lao People's Democratic Republic, Malaysia, Mongolia, Myanmar, Philippines, Republic of Korea, Singapore, Thailand, Timor-Leste and Viet Nam

- South-West Asia: Afghanistan, Iran (Islamic Republic of) and Pakistan

- Near and Middle East: Bahrain, Iraq, Israel, Jordan, Kuwait, Lebanon, Oman, Qatar, Saudi Arabia, State of Palestine, Syrian Arab Republic, United Arab Emirates and Yemen

- South Asia: Bangladesh, Bhutan, India, Maldives, Nepal and Sri Lanka

- Eastern Europe: Belarus, Republic of Moldova, Russian Federation and Ukraine

- South-Eastern Europe: Albania, Bosnia and Herzegovina, Bulgaria, Croatia, Montenegro, Romania, Serbia, the former Yugoslav Republic of Macedonia and Turkey

- Western and Central Europe: Andorra, Austria, Belgium, Cyprus, Czechia, Denmark, Estonia, Finland, France, Germany, Greece, Hungary, Iceland, Ireland, Italy, Latvia, Liechtenstein, Lithuania, Luxembourg, Malta, Monaco, Netherlands, Norway, Poland, Portugal, San Marino, Slovakia, Slovenia, Spain, Sweden, Switzerland and United Kingdom of Great Britain and Northern Ireland

- Oceania: Australia, Fiji, Kiribati, Marshall Islands, Micronesia (Federated States of), Nauru, New Zealand, Palau, Papua New Guinea, Samoa, Solomon Islands, Tonga, Tuvalu, Vanuatu and small island territories 


To celebrate 20 years since its inception, the World Drug Report 2017 is presented in a new five-booklet format designed to improve reader friendliness while maintaining the wealth of information contained within.

Booklet 1 summarizes the content of the four subsequent substantive booklets and presents policy implications drawn from their findings. Booklet 2 deals with the supply, use and health consequences of drugs. Booklet 3 focuses on the cultivation, production and consumption of the three plant-based drugs (cocaine, opiates and cannabis) and on the impact of new cannabis policies. Booklet 4 provides an extended analysis of the global synthetic drugs market and contains the bulk of the analysis for the triennial global synthetic drugs assessment. Finally, Booklet 5 contains a discussion on the nexus between the drug problem, organized crime, illicit financial flows, corruption and terrorism.

Enhanced by this new format, the World Drug Report 2017 is, as ever, aimed at improving the understanding of the world drug problem and contributing towards fostering greater international cooperation for countering its impact on health and security.

The statistical annex is published on the UNODC website: www.unodc.org/wdr/2017 